NBER WORKING PAPER SERIES

\title{
THE WEALTH OF COHORTS: RETIREMENT \\ SAVING AND THE CHANGING \\ ASSETS OF OLDER AMERICANS
}

\author{
Steven F. Venti \\ David A. Wise
}

Working Paper 5609

\author{
NATIONAL BUREAU OF ECONOMIC RESEARCH \\ 1050 Massachusetts Avenue \\ Cambridge, MA 02138 \\ June 1996
}

Funding was provided by the National Institute on Aging through grant number P01-AG05842 and by the Hoover Institution. This paper is part of NBER's research programs in Aging and Public Economics. Any opinions expressed are those of the authors and not those of the National Bureau of Economic Research.

(C) 1996 by Steven F. Venti and David A. Wise. All rights reserved. Short sections of text, not to exceed two paragraphs, may be quoted without explicit permission provided that full credit, including $(\mathcal{O}$ notice, is given to the source. 


\title{
THE WEALTH OF COHORTS: RETIREMENT \\ SAVING AND THE CHANGING \\ ASSETS OF OLDER AMERICANS
}

\begin{abstract}
Personal retirement accounts are becoming an increasingly important form of retirement saving. Using data from the Survey of Income and Program Participation, the paper considers the effect of this change on the assets of recent retirees and persons who are approaching retirement. Much of the analysis is based on comparisons of younger and older cohorts with different lengths of exposure to personal retirement saving programs. The findings suggest that personal retirement saving has already added substantially to the personal financial assets of older families. Projections imply that the personal financial assets of the cohort that will attain age 76 in 28 years will be almost twice as large as the personal financial assets of the cohort that attained age 76 in 1991. The results indicate also that to date there has been little replacement of employer-provided pension saving with personal retirement saving. Together with evidence that personal financial saving is unrelated to changes in home equity, the results suggest that personal retirement saving will lead to an important increase in the overall wealth of the elderly.
\end{abstract}

Steven F. Venti

Department of Economics

Dartmouth College

Hanover, NH 03755

and NBER
David A. Wise

Kennedy School of Government

Harvard University

Cambridge, MA 02138

and NBER 
Americans are changing the way they save for retirement. Contributions to personal saving accounts are becoming an increasingly large proportion of retirement saving while contributions to traditional employer-provided pension plans are declining. The proportion of total contributions accounted for by IRAs, 401(k), and Keogh plans increased from about 7 to over 50 percent during the 1980s. We consider the effect that this change has had on the assets of recent retirees and on persons on the eve of retirement. We find that contributions to personal plans have already added appreciably to the personal retirement assets of older Americans and, by implication, that the effect is likely to be much larger in the future.

The paper emphasizes the changing assets of older Americans. The change has been fueled by the rising popularity of personal retirement saving and thus to evaluate its implications for the financial status of the elderly it is necessary to understand the saving effect of these programs. In a series of earlier papers we considered the saving effects of IRAs. ${ }^{1}$ Venti and Wise [1992] introduced analysis based on comparison of "like families," a version of the cohort analysis structure used in this paper. Poterba, Venti, and Wise [1994, 1995a] considered the saving effect of 401(k) and IRA contributions based in part on the comparison of like families and in part on the "quasi experiment" presented by eligibility for $401(\mathrm{k})$ plans. This paper contributes to that line of analysis, but with a different focus, a different methodology, and a broader scope. We direct attention to families just before and just after retirement. We frame the analysis explicitly in terms of cohorts. The analysis rests primarily on comparison of older and younger cohorts of respondents to the Survey of Income and Program Participation (SIPP) between 1984 and 1991. 
The cohorts had different lengths of exposure to the personal retirement saving plans introduced in the 1980s. Persons who were already retired in the early 1980 s had less opportunity to contribute than persons who were still working when these plans were introduced.

We consider not only whether personal retirement saving contributions substitute for other personal financial assets, as in our previous papers, but also whether they substitute for employerprovided pension assets. To understand the effect of pensions on saving, we need to understand not only how personal retirement saving is related to other personal financial assets, but also how each of these is related to employer-provided pension assets.

Traditional economic assumptions imply that if employers increase saving for employees through employer-provided pension entitlements then employees will save less. Or, if individuals choose to save more through personal retirement saving plans then they will save less in other personal financial assets. Or, if individual housing equity is increased through unanticipated gains in housing prices, then the individual will reduce saving in other forms. The net saving effect of personal retirement saving depends on whether individuals make economic financial decisions in accordance with these assumptions. We find that for the most part these assumptions are inconsistent with observed individual behavior.

\section{BACKGROUND.}

\section{A. Data.}

The analysis is based primarily on 1984,1987 , and 1991 data from the Survey of Income and Program Participation (SIPP). The data are drawn from the 1984, 1985, 1986, and 1990 panels of the survey, with data for the same year sometimes available from more than one panel. The 1984 interview was conducted between September and December 1984 and the 1987 interview 
between January and April 1987, with approximately 28 months between the two interview periods. Thus in the cohort analysis described below we treat this interval as a two-year period. The 1987 and 1991 surveys were conducted almost exactly four years apart. The 1984 to 1991 period is assumed to span six years.

Each panel contains eight interview waves administered every four months over a 32 month period. We use all the waves containing supplemental topical modules requesting detailed information on assets and liabilities and pension plan coverage. These waves are wave 4 of the 1984 panel (administered between September and December 1984), wave 7 of the 1985 panel and wave 4 of the 1986 panel (January to April 1987), and wave 4 of the 1990 panel (February to May 1991). The SIPP household is defined by a physical address. These were reformatted into individual family units headed by either a husband-wife pair or a single individual. Thus a single SIPP household may yield several "families" for the present analysis.

We consider the following asset categories:

- Personal Financial Assets

- Total

- Personal (Targeted) Retirement Assets

- Other Personal Financial Assets

- Employer-Provided Pension Assets

- Social Security Assets

- Home Equity

- Other Non-Liquid Equity

The analysis deals primarily with personal financial assets and employer-provided pension assets. The components of each of the categories are listed in Appendix Table 1. The table pertains to families aged 65 to 69 in 1991 . It reports the proportion of families owning each of the components, as well as the asset mean and median values. The category "personal retirement assets" includes holdings in IRAs, 401(k)s, Keoghs, and life insurance annuities. Respondents 
were not asked for a 401(k) balance for 1984, and thus 1984 totals do not include 401(k) assets. But the mean (and median) 401(k) family balance would have been quite small at that time. These saving plans are grouped together because each narrowly targets saving for retirement, as opposed to saving for other, presumably more short-term, goals. The category "other personal financial assets" encompasses conventional (non-tax advantaged) saving vehicles, including sạving accounts, money market deposit accounts, CDs, NOW accounts, money market funds, U.S. government securities, municipal and corporate bonds, stocks, mutual funds, U.S. Savings Bonds, and other interest earning assets. The category "total personal financial assets" is the sum of personal retirement assets and other personal financial assets. Home equity is the current market value of the home less the unpaid mortgage.

As explained below, the data are used to create means and medians by cohort-all persons who are the same age in a particular calendar year. Thus the same cohort can be followed over successive ages in 1984, 1987, and 1991. However, Social Security and employer-provided pension assets must be calculated from observed benefit payments. Thus wealth in these forms is available only for persons who are retired and we typically consider them only for persons over 65. The present values are obtained by capitalizing the stream of monthly income from each source using sex-specific survival probabilities calculated from mortality tables. ${ }^{2}$

\section{B. Family Wealth at Retirement.}

Social Security benefits provide the vast majority of the income of a large fraction of retired Americans, and the present value of expected future benefits is the major component of the wealth of most elderly families. In 1991, the median Social Security wealth of families with heads 65 to 69 was about $\$ 100,000$. (See Figure 1a.) Median employer-provided pension wealth 
(including government and military pensions) was only $\$ 16,017$. Pension wealth is distributed much more unevenly than Social Security wealth -44 percent of families 65 to 69 have no pension income at all. The median level of housing equity was $\$ 50,000$, but housing equity is typically not used to support consumption of the elderly, at least not until quite advanced ages. ${ }^{3}$ The median level of other non-liquid assets, such as cars and business equity was only $\$ 5,992$. Personal saving through conventional channels represents a very small proportion of the assets of most older families; the median level of (other) personal financial assets was only $\$ 7,428{ }^{4}$ Thus most families, if they spend the income provided by Social Security and employer pension annuities, have almost no liquid accessible assets to meet unexpected expenditures. More than half of families had neither IRA nor $401(\mathrm{k})$ accounts so that the median wealth in personal retirement assets was zero.

Although the median is the best single measure of the assets of the typical family, the components of wealth other than Social Security are highly skewed so that the means are much larger than the medians. The mean level of other personal financial assets in 1991 was $\$ 42,018$, more than five times the median. But even mean other personal financial assets are a small fraction of combined Social Security and employer-provided pension assets, as indicated in Figure $1 b$.

The means, however, reveal the increasing importance of IRA and 401(k) assets as a fraction of total personal financial assets. For families aged 65 to 69 , personal retirement assets were only 6.6 percent of total personal financial assets in 1984 , they represented 20.6 percent by 1991. Personal retirement assets increased over four fold between 1984 and 1991, much more than any other component of wealth, as shown in Figure 1c. 


\section{Aggregate IRA and 401(k) Saving.}

Total contributions to IRA and 401(k) accounts over the 1980s are shown in Figure 2. IRA contributions jumped enormously in 1982 as soon as they became available to all wage earners and then increased to a peak of over $\$ 38$ billion in 1985 . Contributions dropped dramatically after the Tax Reform Act of 1986, that limited the tax-deductibility of the contributions of families with incomes over $\$ 40,000$ per year and single persons with incomes over $\$ 25,000$. Even though only 27 percent of contributors were affected by the legislation, ${ }^{5}$ contributions fell by over 60 percent, with a dramatic decline even in the contributions of persons who were unaffected by the legislation. The implications of this decline are discussed in detail in Poterba, Venti, and Wise [1994, 1995a]. By 1990 , less than $\$ 10$ billion was contributed to IRA accounts.

Contributions to 401(k) plans increased consistently from their introduction in 1982 to $\$ 49$ billion in 1990, the most recent date for which data are available. Extrapolation of past trends would suggest that contributions are now between 60 and 70 billion. Figure 2 reveals no relationship between IRA and 401(k) contributions, with the annual increase in 401(k) contributions about the same after as before the 1987 decline in IRA contributions.

The relationship between these contributions and contributions to other retirement saving plans (excluding Social Security) is shown in Figure 3a. Contributions to defined benefit pension plans declined almost 40 percent, from $\$ 48.4$ billion in 1980 to $\$ 24.9$ billion in 1989 . This decline was apparently due primarily to the large unexpected returns to pension fund assets over the 1980s, as described in Bernheim and Shoven [1988]. The decline may have been induced also in part by the funding limits imposed by the Omnibus Budget Reconciliation Act of 1987, as explained in Schieber and Shoven [1993]. Participants in defined benefit plans declined only 9.3 
percent and the number of plans by 10.5 percent between 1980 and 1989 . Contributions to defined contribution plans remained about the same over the entire period. ${ }^{6}$

Personal targeted retirement saving represented only 7.6 percent of the total in 1980 but had increased to over 50 percent of the total by 1989 . It seems apparent that if IRA contributions had not been curtailed by the 1986 legislation, balances in these accounts would have represented a much larger fraction of contributions to all retirement plans and total contributions would have been substantially larger. The trend in total contributions displayed in Figure 3a closely follows the trend in IRA contributions.

Total personal saving as measured by the Federal Reserve Board's Flow of Funds (FOF) accounts, is shown in Figure 3b. These data include contributions to targeted retirement saving plans, as well as other components of saving. The FOF data are based on direct measurement of the net acquisition of assets and are thus more comparable to the targeted retirement saving components than the National Income and Product Account (NIPA) data, the most often cited measure of aggregate personal saving. The NIPA data estimate saving as the residual between disposable income and personal consumption expenditures. The FOF data include several assets not incorporated in the NIPA definition of saving. ${ }^{7}$ Thus, in addition to the more inclusive FOF series, the Federal Reserve Board also publishes a series that attempts to match the components of saving that are in principle included in the NIPA measure-indicated by "FOF NIPA Basis" in Figure 3b. But even after the adjustment, the NIPA and FOF measures often differ by tens of billions of dollars. They are discussed in some detail in Poterba, Venti, and Wise [1995b].

Targeted retirement contributions represent a large fraction of FOF national saving. In 1986, for example, retirement plan contributions accounted for 72.3 percent of FOF NIPA Basis 
data and 30.9 percent of the unadjusted FOF series. Both measures tend to follow the pattern of targeted retirement saving in Figure 3a, which in turn follows the pattern of IRA contributions. In particular, both measures show a substantial increase in saving between 1980 and 1986, both show a noticeable fall in saving after the 1986 legislation, and then a recovery by 1989 .

The goal of the subsequent analysis is to assess the impact of personal retirement saving on the financial status of older Americans as they approach and enter retirement. Two issues are considered. First, using cohort data, the relationship between personal retirement saving and other personal financial assets is considered in section 2. Second, the relationship between total personal financial assets and employer-provided pension assets is considered in section 3 . We direct attention only briefly to the relationship between housing wealth and personal financial assets, but that relationship has been analyzed recently by Hoynes and McFadden [1993]. who find little relationship between changes in housing equity and personal financial assets. We rely on their results in making summary judgements about the net effect of personal targeted retirement saving on the financial assets of older Americans. In his review article on the relationship between housing equity and wealth, Skinner [1991] also concludes that there is little or no relationship between housing equity and other financial asset saving.

\section{PERSONAL RETIREMENT SAVING AND OTHER ASSETS: COHORT ANALYSIS.}

\section{A. Cohorts and Cohort Data.}

We begin with a discussion of the principle elements of cohort analysis. A cohort is typically a group of persons that are born in the same year. Thus persons who are a given age in 1984 are also a cohort. Cohort analysis usually means that the same cohort is followed over time. That is, persons who are age 50 in 1984 can be observed in 1985, 1986, and so forth. Panel data 
is designed to follow specific individuals over time. For example, the mean wealth of persons who are 50 in 1984 can be traced over time, considering the mean wealth of these same persons in 1985, in 1986, and so forth. From panel data, the cohort means are obtained directly by following the same persons over time. But cohort means can also be obtained from random samples of the population in successive years (a series of cross-sections). We use the SIPP data in this way, although these data also include a short panel component, following the same people for 32 months. Using these data, the mean assets of a random sample of persons who are 50 in 1984 are compared to the mean assets of another random sample of persons who are 51 in 1985 , 52 in 1986 , and so on.

We have made calculations for 15 cohorts defined by age in 1984: C42, C44, .., C70. For ease of exposition we usually show data graphically for only a subset of the cohorts. In fact, each cohort is defined by all persons within a 5-year age interval in 1984. For example, C42 refers to the midpoint of the interval that includes people between 40 and 44 in 1984, 41 and 45 in 1985 , etc.

For illustration, mean personal retirement saving assets are graphed for five cohorts in Figure 4a. For each cohort, assets are reported for 1984, 1987, and 1991. For example, the mean of personal retirement assets of cohort C46 was about $\$ 1,800$ in $1984, \$ 4,500^{\circ}$ in 1986 , and $\$ 11,700$ by 1991 . Increases for the C52 and C58 cohorts are also large. But the increases for the older cohorts are much smaller. The C70 cohort, that was past typical retirement age in the early 1980s when the programs were introduced, accumulated very little in personal retirement assets. That is, the relationship between age and the accumulation of personal retirement assets depends strongly on the cohort. 
Notice that the relationship between age and asset accumulation judged by the cross-section profile is grossly misleading in this case. For example, the difference between the assets of 46 and 52 year olds in 1984 is much less than the assets actually accumulated by cohort C46 between age 46 (in 1984) and age 52 (in 1991). In Figure 4a the cross-section relationship between age and assets can be obtained by linking the values reported for a given year. For example, 1991 values are reported for ages $52,58,64,70$, and 76 , highlighted by the small circles. Similarly, the 1984 values-for ages $46,52,58,64$, and 70 -are highlighted by the triangles. In both cases the cross-section relationship gives a distorted view of the actual accumulation of personal retirement assets with age. This is because the large "cohort effects" are unrecognized in the cross-section relationship.

The different levels of asset accumulation by different cohorts at specific ages provide the core data to evaluate the net saving effect of personal retirement saving contributions. The differences are called "cohort effects" and can be judged directly by the difference in assets of cohorts that attained a given age in different calendar years. At a given age, different cohorts had different lengths of exposure to personal retirement saving programs, that were widely available beginning in 1982. For example, cohort C46 that attained age 52 in 1991 accumulated much greater personal retirement assets by age 52 than cohort C52 that attained age 52 in 1984 and thus, by that age, had had many fewer years to accumulate these assets. The same is true for cohorts C52 and C58 at age 58, C58 and C64 at age 64, and C64 and C70 at age 70.

To facilitate exposition, we often fit the three data points for each cohort and graph the fitted values, as shown in Figure $4 b$. In this way it is possible to visualize many more cohorts on the same graph. 
Mean personal retirement assets for all 15 cohorts are shown in Appendix Table 2. The data for each cohort is in a separate column and the relationship between age and assets within a cohort is shown by the asset values moving down the column. Cross-section relationships for 1984 are shown in the "top" diagonal, for 1987 by the middle diagonal, and for 1991 by the lower diagonal. As indicated in Figure 4, the differences are extremely large.

In the subsequent analysis we will consider whether cohort effects like those shown for personal retirement assets in Figure 4 are offset by countervailing cohort effects with respect to other personal financial assets. For example, Figure 4a shows that persons who attained age 52 in 1991 had much larger personal retirement assets that persons who reached age 52 in 1984 . The key question is whether the larger personal retirements were offset by a reduction in other personal financial assets. If the personal retirement asset cohort effects are offset by countervailing cohort effects in other personal financial assets, there will be no cohort effects in total personal financial assets; it they are not offset, the personal retirement asset cohort effects will be mirrored by similar cohort effects in total personal financial assets. Equivalently, if there are no cohort effects with respect to other personal financial assets, this implies that the personal retirement asset cohort effects are not canceled by offsetting cohort effects in other personal financial assets. To highlight the cohort effects, most of the evidence is presented graphically. We also use more formal estimates of cohort effects to project the future retirement assets of younger cohorts.

\section{B. Personal Retirement Assets and Other Personal Financial Assets}

We begin by considering the assets of all respondents to the SIPP, including both contributors and non-contributors. The basic assumption is that younger cohorts-that reached a given age in later calendar years-had a longer period in which to contribute to personal 
retirement accounts. But that in other respects the cohorts are similar (after correcting for earnings differences between cohorts that attained a given age in different years). Thus differences in asset accumulation can be attributed to the differential availability of these programs. The implicit assumption is that the differences are not due to a systematic trend in the "taste" for saving. The data for contributors and non-contributors together provide the most compelling evidence on substitution because these data are not confounded by the potential changing composition of contributors and non-contributors, which may change the saving propensities of the two groups over time.

Contributors to personal targeted retirement saving programs and non-contributors are then considered separately. In this case, it is proposed that the cohort differences among contributors result from the differences in exposure to the special retirement saving programs. For example, contributors who attained age 52 in 1991 have larger personal retirement assets than contributors who reached age 52 in 1991 because the former group had had seven more years to contribute to these programs. These data can be used to judge the effect of the retirement saving programs on the future asset accumulation of those who participate in such programs. In addition, the cohort effects of contributors can be compared to the cohort effects among non-contributors. The noncontributor cohort effects might be considered an indication of cohort effects that would have obtained in the absence of the special retirement saving programs. That is, it might be assumed that any systematic trend in the "taste" for saving would be revealed in a cohort effect among noncontributors. The results will show that for the most part there are no cohort effects among noncontributors. Comparisons of contributors and non-contributors must be interpreted with caution, however, have very different saving propensities, as the data discussed below will show. Thus 
it is questionable whether data for non-contributors can be used to infer the saving of contributors had they not participated in the programs. For contributors, cohort effects are observed with respect to personal retirement assets but not with respect to other personal financial assets. Indeed, for all respondents together, there are no cohort effects with respect to other personal financial assets. Cohort effects are only observed with respect to the personal retirement assets of contributors. Thus we believe it unlikely that the results can be attributed to a general shift in the taste for saving over time.

To simplify the graphical exposition, we sometimes show the actual data for "nonoverlapping cohorts," as in Figure 4a. Or, we present fitted values like those in Figure 4b. We would like to emphasize the assets of the typical family and thus would prefer to use median values. In addition, the medians are less subject to random fluctuation due to extreme outliers. As explained above, however, in some instances the medians are not informative (when fewer than 50 percent of families own an asset) and we present only means.

An issue that arises in the cohort analysis is the appropriate comparison of the assets of persons who attained a given age in different calendar years. If our goal were to compare the purchasing power of different cohorts, a price index would be the most appropriate measure by which to put different calendar year data on a common basis. Here, however, the issue is not purchasing power but rather the saving that would have occurred in the absence of the personal retirement saving programs. There are at least two possibilities: One is to assume that the increase (or decrease) in other personal financial asset saving that would have occurred in the absence of the personal retirement saving programs is the percent increase in this asset category among non-contributors. Averaged over ages 48 to 68 the increase was 3.8 percent between 1984 
and 1991. Another conceptual approach is to base the correction on the nominal earnings of successive cohorts, assuming that other personal financial asset saving is based on earnings, and, that there would have been no real cohort effects in personal financial asset saving in the absence of the personal retirement saving programs. The closest empirical approximation to this conceptualization may be an earnings index. For illustration, we present some results in nominal dollars, but most of the results are based on values converted to 1984 dollars using the wage and salary component of the Bureau of Labor Statistics Employment Cost Index.

\section{All Respondents: Means.}

\section{a. Nominal Values.}

The mean personal targeted retirement assets of cohorts C46, C52, C58, C64, and C70 are shown in Figure 5a. As described with respect to the illustrative figure above, younger cohorts, that attained any specific age in a later calendar year and thus at that age had had longer exposure to the special retirement saving plans introduced in the early 1980 s-accumulated much larger personal retirement assets. For example, cohort C58 accumulated the highest level of personal retirement assets. Members of this cohort were age 56 to 60 in 1984 and 54 to 58 in 1982 when the IRA and 401(k) programs were expanded, and were age 62 to 66 when last surveyed in 1991. The C70 cohort accumulated the lowest level of personal retirement assets. Members of this cohort were already age 66 to 70 and past retirement in 1982 and thus were in large part unable to take advantage of the IRA and 401(k) programs.

The corresponding means of other personal financial assets of the same cohorts are shown in Figure $5 \mathrm{~b}$. The accumulation of personal retirement assets-described above-differed greatly by cohort. The corresponding accumulation of other personal financial assets also shows a cohort 
effect, but not one that offsets the retirement asset cohort effect; younger cohorts also have higher levels of other financial assets. Because the rapid accumulation of retirement assets was not offset by a reduction in the accumulation of other financial assets, the accumulation of total personal financial assets also shows strong cohort effect, with younger cohorts-who attained any age in a later year-typically accumulating more personal financial assets, as shown in Figure 5c. Both total and retirement assets for three cohorts are shown in Figure 5d. At age 58, for example, the difference in retirement assets of cohorts 52 and 58 can be compared directly to the difference in the total personal assets of these cohorts. The same comparison can be made for cohorts 58 and 64 at age 64 .

\section{b. Indexed Values-Fitted.}

Fitted values of total and retirement assets for eight cohorts are shown in Figure 5e. The vertical lines are to aid in comparing the cohort differences in total and retirement assets at given ages. If there were no reduction in the other financial assets of successive cohorts as they increased their personal retirement assets, the difference in the total would be equal to the difference in retirement assets. The average of the ratios of the total to the retirement asset difference is 1.16 . There is of course some randomness in these ratios. But the data suggest that the accumulation of personal retirement assets resulted for the most part in a corresponding increase in total personal financial assets. Fitted values for other personal financial assets are graphed in Figure 5f. They reveal essentially no systematic cohort effect.

\section{c. Indexed Values-Actual And Projected.}

The results above show that each of the successively younger cohorts has greater personal financial assets than the preceding older cohort. What the personal financial asset levels will the 
younger cohorts have accumulated by the time they reach the age of the oldest cohort? Although it is improbable that future asset levels can be precisely predicted, we believe that the data allow plausible projections of the future assets of the younger cohorts. We fit the indexed actual cohort means with a specification of the form

$$
A_{i c}=\alpha+\beta_{c}+\gamma_{1}\left(A g e_{i}\right)+\gamma_{2}\left(A g e_{i}\right)^{2}+\gamma_{3}\left(A g e_{i}\right)^{3}+\varepsilon_{i c}
$$

where A represents an asset category-personal retirement assets, other personal financial assets, total personal financial assets $-c$ indexes cohort and $i$ the ith cohort mean. The $\beta_{c}$ are cohort effects with $\sum \beta_{c}=0$. Thus the individual estimates represent deviations from the mean effect, which is set to zero. The specification is intended to fit the age-asset accumulation pattern, allowing the differences in the levels of the assets between successive cohorts to be maintained as the cohorts age, and to cumulate. It is assumed, for example, that the estimated difference between the assets of the two youngest cohorts, $\mathrm{C} 42$ and $\mathrm{C} 46$, will be maintained as the cohorts age. Thus the projected difference at age 76 in the asset levels of cohorts $\mathrm{C} 42$ and $\mathrm{C} 70$, for example, is given by the difference between $\mathrm{C} 42$ and $\mathrm{C} 44$, plus the difference between $\mathrm{C} 44$ and C46, plus the difference between $\mathrm{C} 46$ and $\mathrm{C} 48$, and so forth. Indeed, it is convenient to think of the estimated cohort effects as representing the projected cohort differences at age 76 . It is likely that this assumption implies a conservative estimate of the projected cohort differences. Constant percentage differences as the cohorts age, for example, imply much larger age 76 cohort differences.

The estimates are shown in Table 1a. The projected personal retirement assets (column 1) of the youngest cohort are $\$ 14,076$ above the mean while the projected assets of the oldest 
cohort are $\$ 13,105$ below the mean, a difference of $\$ 27,181$. If there were no counterbalancing cohort effects with respect to other personal financial assets, the total personal financial asset cohort effects should approximately parallel the retirement asset cohort effects. The estimates show that the projected total (column 2) for the youngest cohort is $\$ 16,003$ above the mean and $\$ 14,083$ below the mean for the oldest cohort, a difference of $\$ 30,086$. The other personal financial asset cohort effects are typically not statistically different from zero. An F-test does not reject the hypothesis that there are no cohort effects, that is, that all the individual effects are zero.

The projections of total personal financial assets based on equation (1) are graphed in Figure 5g. The age 76 personal financial assets of the oldest cohort are $\$ 37,299$; the projected age 76 assets of the youngest cohort are $\$ 67,385$, an increase of over 80 percent.

2. Contributors and Non-Contributors Separately: Indexed Means.

a. Indexed Values-Fitted.

Because only a minority of respondents contribute to a personal retirement saving account-only about 40 percent of cohorts who were younger than 65 in 1984 and a much smaller percent of older cohorts-the total saving effect of the participants is diluted by the larger number of respondents that did not participate and were apparently unaffected by these saving programs. Thus we also present data for contributors and non-contributors separately. The findings based on means are shown in Figures 6a through 6c. Again, cohorts who reached a given age in a later calendar year, had accumulated much more in personal retirement accounts than cohorts who reached that age in an earlier year. These differences are reflected, for the most part, in corresponding differences in total personal financial assets, as shown in Figure 6a. And, as with 
both contributors and non-contributors together, the cohort data for other personal financial assets of contributors show essentially no systematic cohort effects. (See Figure 6b.)

For comparison, the accumulation of personal financial assets of non-contributors is shown in Figure $6 \mathrm{c}$. There appear to be no cohort effects among non-contributors at younger ages. At older ages, older cohorts appear to have slightly higher personal financial asset levels. This may be because a smaller proportion of older cohorts ever contributed to a personal retirement plan, and thus the non-contributors among the older cohorts disproportionately include "savers" that if they were younger would have contributed to a personal retirement account. This composition effect is discussed below with reference to Table 2 .

\section{b. Indexed Values-Actual and Projected.}

Projected means (indexed to 1984) of contributors are shown in Figure 6d together with actual values for selected cohorts. The projected age 76 total personal financial assets of cohort C70 (in 1991) is $\$ 93,151$; the projected value of the $\mathrm{C} 42$ cohort at age $76-18$ years hence-is

$\$ 160,175$. As with both contributors and non-contributors, the estimated cohort effects for total personal financial assets tend to mirror the estimated effects for personal retirement assets, as shown in Table 1b. The estimated cohort effects for other personal financial assets are not typically statistically different from zero. (The estimates, however, reveal an apparent composition effect among older cohorts and this is discussed below.) Thus for participating families the cumulative effect of personal retirement account contributions is very large. Assuming no cohort effect with respect to other personal financial assets, personal retirement assets would increase over the next 18 years from 22 to 50 percent of the total personal financial assets of age 76 families. 


\section{Contributors and Non-Contributors Separately: Indexed Medians.}

a. Indexed Values-Fitted.

As mentioned above, the distribution of financial assets is highly skewed so that means are much larger than medians. Thus the median is a much better indicator of the assets of the typical family. Medians for all respondents are not informative, however, because the median for personal targeted retirement assets is typically zero. Median total and retirement assets for contributors are shown in Figure 7a. Like the means, the medians also show that younger cohorts accumulated much larger levels of personal retirement assets than older cohorts. The larger accumulation of retirement assets was not offset by a corresponding reduction in the accumulation of other personal financial assets (Figure 7b), that show no substantial off-setting cohort effects. Thus younger contributor cohorts are accumulating much larger levels of total financial assets (Figure 7a) than their older counterparts.

The medians for non-contributors are shown in Figure 7c. These data show extremely low levels of financial assets and essentially no cohort effects at younger ages. As mentioned above, the "apparent" cohort effect for the oldest cohort apparently reflects a composition effect; most of the oldest respondents were non-contributors, and thus had greater assets than younger cohort non-contributors.

\section{b. Indexed Values-Actual and Projected.}

Like the means, the projected median values of total personal financial assets show very large cohort effects that tend to mirror the cohort effects for personal retirement assets, as shown in Table 1c. Recall that unlike means the sum of the medians if not the median of the sum, and thus the estimated cohort effects cannot be "added" across equations. Most of the estimated cohort 
effects for other personal financial assets are not statistically different from zero, although an apparent composition effect is reflected in the estimated cohort effects among older cohorts. Nonetheless, it is clear that younger cohorts of participating families are accumulating much more in total personal financial assets than older cohorts. The projected median of current age 76 families (cohort C70 in 1991) is $\$ 62,388$; the projected accumulation of the youngest cohort by age 76 is $\$ 107,138$.

\section{Summary of Age-Specific Cohort Effects by Contributor Status: Means and Medians.}

The graphs of the cohort data show the accumulation of assets with age for successively older cohorts. The different levels of asset accumulation by different cohorts at specific ages provide the core data to evaluate the net saving effect of personal retirement saving contributions. As discussed above, the single most informative comparison is for both contributors and noncontributors combined, considering the change in other financial assets (or in total financial assets) as the personal retirement assets of respondents increased. These data are not confounded by possible changes in the composition of contributors, and of non-contributors, as the proportion of contributors increased between 1984 and 1991. But comparisons for contributors and noncontributors separately are also informative: we consider the change in the other financial assets (or in the total financial assets) of contributors as their personal retirement assets increased. But other financial assets may have increased or decreased for other reasons as well. One way to judge the effect of other influences is to consider the change in the financial assets of noncontributors. As mentioned above, however, because of apparent large differences in saving propensity, non-contributors may be an inadequate "control" group with which to judge the behavior of contributors in the absence of the retirement saving programs. And, the comparison 
of cohort data for contributors and non-contributors may be may be affected by "composition" effects. For example, the proportion of contributors in the 65 to 69 age interval increased from 19 to 35 percent between 1984 and 1991. Thus, for example, "saver" families may have disproportionately become contributors, leaving a larger concentration of "non-savers" in the noncontributor group in 1991. If this were the case, non-contributors would not serve as a homogeneous control group with which to compare the contributors. To help to address this changing composition issue we have estimated the mean assets of all respondents -- both contributors and non-contributors -- and the mean and median assets of contributors and noncontributors separately, controlling for income, age, marital status, and gender of the family head. The 1984 and 1991 means and medians for three age groups spanning typical retirement ages are shown in Table 2. The means are evaluated at the 1987 means of the income and demographic variables and the medians are evaluated at the medians of the income and demographic variables. Thus the estimates reflect values that would have obtained if the income and demographic characteristics of pools of contributors and non-contributors remained at 1987 levels in all years. All values are in 1984 dollars. (The conditional medians are somewhat larger than the unconditional medians. Thus, for example, the conditional financial medians of non-contributors may be 50 percent higher than the overall medians of the financial assets of non-contributors.) Data for all three years and for additional age intervals are shown in Appendix Tables 3a and 3b. Consider the age 60-64 means, for example. Considering both contributors and noncontributors combined, the mean retirement saving assets of families who were in this age interval in 1984 was $\$ 3,946$, compared to a mean of $\$ 10,914$ for those who did not attain this age until 1991. But this large increase in retirement saving assets was not accompanied by a substantial 
decline in other personal financial assets, which remained virtually unchanged $(\$ 28,629$ in 1984 and $\$ 27,959$ in 1991). Consequently, there was a large increase in total personal retirement assets, from $\$ 32,575$ to $\$ 38,874$. For contributors, mean targeted retirement saving increased from $\$ 9,968$ for the oldest cohort (those who were in this age interval in 1984) to $\$ 25,795$ for the youngest cohort (who attained this age interval in 1991). There was little corresponding change in other personal financial assets, however, a decline of from $\$ 51,397$ for the oldest cohort to $\$ 50,160$ for the youngest cohort. Total personal financial assets increased by 24 percent, from $\$ 61,365$ to $\$ 75,954$. In contrast, the assets of non-contributors declined by 6 percent, from $\$ 13,468$ to $\$ 12,684$. Because of the additive property of means, the $\$ 15,827$ increase in the targeted retirement saving assets of contributors can be compared to the $\$ 14,589$ increase in total personal financial assets. Similar trends are revealed for the other age groups.

The medians in Table 2 show a similar pattern. There is typically a large increase in the personal retirement assets and in the total financial assets of contributors and only a small decline in other financial assets. In contrast, the median personal financial assets of non-contributors typically declined more than the median of other personal financial assets of contributors and the percentage decline was typically much greater. Because financial asset are so skewed, the medians provide a better measure than the means of the wealth of the typical family. But because medians are not additive, direct comparison between the increase in retirement assets and the increase in total financial assets does not provide an unambiguous measure of the extent of substitution. Appendix Tables 3a and $3 \mathrm{~b}$ show much the same pattern but with some variation among the age intervals and from year to year. 
In addition, the tables show the proportion of each age group that has a personal retirement saving account. The proportion with retirement accounts does not vary much by age or cohort for persons younger than 64 . Nor does the proportion vary much for the oldest age group, of which very few in any cohort had accounts. But older cohorts, in the 65 to 69 and 70 to 74 age intervals in particular, were much less likely than the younger cohorts to have personal retirement accounts. Thus the decline in the total personal financial assets of non-contributors in the 65 to 69 age interval (as the proportion in the non-contributor status declined from .81 to .65 ) may result in part from a "composition" effect, with "savers" increasingly likely to be contributors. This effect may be reflected in the older cohort data graphed in Figures $6 \mathrm{c}$ and $7 \mathrm{c}$ and the data must be interpreted accordingly. But the conditional means and medians should help to control for this composition effect. Judging by the proportion of contributors, the data for "pre-retirement" ages and for the oldest ages are probably not importantly affected by this changing composition in either case.

\section{PERSONAL RETIREMENT SAVING AND EMPLOYER-PROVIDED PENSION ASSETS.}

Tradeoffs between personal retirement saving and other personal financial asset saving may provide the most readily available opportunity for substitution from one form of saving to the other. But personal retirement saving could also substitute for employer provided pension assets. Persons who foresee larger employer-provided retirement benefits may be less likely to contribute to a 401(k) plan, or to an IRA account, or to accumulate other personal financial assets. Thus we consider whether families with more pension wealth have less wealth in total personal financial assets.

There are two circumstances that condition the analysis: first, the SIPP data do not allow calculation of employer-provided pension wealth until a person is retired and receiving pension 
benefits. The benefit, together with life tables, can be used to determine the present value of expected future pension benefits-pension wealth. Thus cohort analysis as presented above is not suitable in this case. Second, both pension wealth and personal financial asset saving will increase with income, thus without controlling for income persons with greater personal financial wealth would almost certainly have greater pension wealth as well. Thus we consider the relationship between personal financial assets and pension wealth for persons 65 to 69 , who have retired and for whom we can determine pension wealth. And we use Social Security wealth percentiles to control for lifetime income. ${ }^{8}$ The relationship between Social Security wealth and lifetime income is very non-linear, with less than proportionate increases in Social Security wealth as lifetime income increases. But we believe that the percentile level provides the best available means of grouping people by lifetime income.

Using an analysis of variance framework, we estimate the relationship between pension wealth and three personal financial asset categories: personal retirement assets, other personal financial assets, and total personal financial assets. The specification is of the form

$$
A_{i}=a_{i}+b_{i}(\text { PensionWealth })+c_{i}(\text { Education })+e_{i},
$$

where $\mathrm{i}$ indicates the ith Social Security wealth decile and A denotes a personal financial asset category. We control for education because saving is typically found to increase with years of education, given income.

The parameter estimates on pension wealth are reported in Table 3 for each of the personal asset categories and for each of the years 1984,1987 , and 1991 . The estimates are typically small but suggest that a dollar more in pension wealth is associated with from 4 cents less to 19 cents more in total personal financial assets in 1991, although most estimates are not statistically 
different from zero. Essentially the same results are obtained if education is excluded from the specification. And, the same results are obtained if home equity is added to the specification, to control for other wealth that could in principle be used to meet financial needs after retirement. Thus we conclude that there is unlikely to be much if any substitution of personal financial saving for employer-provided pension entitlement.

We obtain essentially the same results when equation (1) is estimated separately for persons with and without a college degree. If anything, the results are stronger for persons with college degrees. That is, the estimated coefficients are somewhat larger for the college educated group. This result is apparently at variance with the recent results of Bernheim and Scholz [1993], who find no substitution for persons without a college degree but a positive substitution effect for persons with a college degree. Their estimates are based on the Survey of Consumer Finances and pertain to persons who are not yet retired. They use an indicator variable for pension coverage, whereas we use pension wealth just after retirement. Their measure of personal assets includes business equity and property other than primary home, whereas we include only personal financial assets. Our ANOVA specification also aims to capture lifetime earnings differences and allows for complete interaction by Social Security wealth percentile.

Several other previous studies have considered the impact of employer-provided pensions on personal saving. The early work of Cagan [1965] and Katona [1965] found that persons covered by an employer pension save more in other forms. Cagan attributed this to a "recognition effect," whereby pension coverage induces awareness of the need to save for the future. More recently, several studies have sought to update and add to this line of analysis by relating personal saving to expected pension wealth, instead of pension coverage. These studies have focused on 
older persons who are not yet retired and for whom the pension-saving tradeoff may be greatest. The results have been mixed, perhaps because it is difficult to calculate pension wealth accurately for persons who are not yet retired. Munnell [1976] finds a substantial offset, as high as 62 cents for each dollar of estimated pension wealth. Blinder, Gordon, and Wise [1981], Hubbard [1985], and Avery, Elliehausen, and Gustafson [1986], however, find little or no evidence of a tradeoff; Diamond and Hausman [1984] find a modest tradeoff. Thus these findings would suggest that the tradeoff is far from dollar for dollar and the consensus view appears to be little or no effect.

Possibly the principle reservation about the previous studies is the difficulty of constructing an accurate measure of expected pension wealth for persons prior to receipt of pension benefits. Such calculations require assumptions about job mobility, future earnings, time to retirement, and, most important, pension plan provisions. The detail necessary to calculate pension wealth is are not reported in any of the data used by previous investigators, with the exception of the Survey of Consumer Finances used by Avery, Elliehausen, and Gustafson [1986]. Thus we have directed attention to recently retired persons and have used Social Security wealth percentiles to control for lifetime income.

\section{HOUSING EQUITY.}

Rapid increases in housing prices led to large increases in home equity in many parts of the country over the 1980 s. Data for selected cohorts -- indexed to 1984 dollars -- are shown in Figure 8. Substantial cohort effects are apparent, but whether the younger or the older cohort has more housing equity varies with age. In cohorts that reached ages 58,64 , and 70 in 1991 had more wealth in housing equity than the older cohorts that reached these ages earlier, in 1984. Thus the younger cohorts that attained these ages in a later year had not only accumulated more 
housing equity, the younger cohorts had accumulated more housing equity wealth as well. For many, the increase in housing equity was probably an unanticipated windfall gain. Thus it might be expected that there would be even more inducement to reduce other personal financial asset saving, contrary to the findings reported above. This is typically true for ages above 58 . At 52, however, the younger cohort has less housing equity than the older cohort and this is typically true at ages less than 58. More discussion of cohorts and housing equity with particular attention to the effect of the Tax Reform Act of 1986, which may have encouraged home equity loans, is presented in Poterba, Venti, and Wise [1996].

Notice that the figure shows an increase in housing equity between 1984 and 1991 for each cohort, even for the cohort that ages from 70 to 76 between 1984 and 1991. Cross-section data, however, would show a misleading decline in housing equity at older ages. The 1991 crosssection data, represented by the 1991 values at $52,58,64,70$, and 76 , show home equity declining after age 64. Older cohorts have less housing equity than younger cohorts, but not because they reduce housing equity as they age.

We have not attempted in this paper to consider formally the relationship between personal financial asset saving and housing equity. Hoynes and McFadden [1993] have recently completed an analysis of this issue. They find essentially no relationship between increases in home equity and total personal financial asset saving, based on data from the Panel Survey of Income Dynamics (PSID). They are able to follow the same persons over an extended time period. The SIPP data follow the same persons for only 30 months and the cohort method we use in section two does not provide a sufficient number of cohorts to perform a meaningful comparison of 
changes in home equity versus changes in personal financial assets by cohort. Skinner [1991] also finds little relationship between housing equity and personal financial assets.

\section{CONCLUSIONS.}

Personal targeted retirement accounts are an increasingly important form of saving for retirement. By 1989, contributions to IRA, 401(k), and Keogh accounts exceeded contributions to traditional employer-provided defined benefit and defined contribution pension plans. We have emphasized the effect of this form of saving on the financial status of recent retirees and on persons approaching retirement. Based on comparison of younger and older cohorts, we conclude that, for the most part, the increasing contributions to personal retirement plans have not displaced other financial asset saving. And consequently the real personal financial assets of younger cohorts are substantially larger than the assets of their predecessors. Although any projections must be imprecise, the conservative estimates that we have made suggest that age 76 families 18 years in the future will have almost $\$ 25,000$ more in a personal financial assets than current 76 year old families-about $\$ 67,000$ versus $\$ 43,000$. The personal financial assets of participating families will be $\$ 67,000$ higher at age $76-\$ 93,000$ versus $\$ 160,000$.

Using Social Security wealth percentiles to control for lifetime income, we find that thus far there has been little replacement of employer-provided pension entitlements with personal retirement saving. Nor do we find any reduction in other personal financial asset saving with increases in employer-provided pension wealth. Thus we conclude that, for the most part, the personal retirement saving of recent retirees has not replaced firm pension plan saving by employers, nor have employer pensions displaced other personal financial assets. This should not be interpreted to mean that employer pensions have no effect on individual behavior. It seems 
apparent that employer pensions together with Social Security have led to dramatic declines in typical retirement ages and the labor force participation of older Americans. Thus even if pensions have not reduced the amount that employees save in other forms, they surely have reduced the amount that older persons earn. This issue is discussed in some detail in Lumsdaine and Wise [1990].

Because we can find no apparent offset to the increase in personal retirement saving, we believe that this form of saving will not only be an increasingly important component of the wealth of the elderly, but indeed holds the prospect of adding substantially to the financial status of older Americans. In particular, personal retirement saving is likely to increase substantially the nonannuitized liquid financial saving of older families.

If these trends continue, the baby boom generation will accumulate substantially larger levels of personal financial assets than their older counterparts and thus after retirement will have much larger pools of accessible assets upon which to draw to meet unexpected contingencies. 


\section{Notes}

1. Results using different data sets and different methodologies are presented in Venti and Wise $[1986,1987,1990 \mathrm{~b}, 1992]$. The findings of other investigators of this issue-Gale and Scholz [1990], Feenberg and Skinner [1989], and Joines and Manegold [1991] —are summarized in the last paper.

2. A discount rate of 6 percent is used. Social Security, Railroad Retirement, federal employee, and military pensions are indexed by law. About 75 percent of state and local public employees receive some post retirement benefit increase; about half receive automatic COLAs (Phillips (1992). Post-retirement benefit increases in the private sector are less common. Gustman and Steinmeier (1993) found that during the 17 year period ending in 1987, that included a period of high inflation, about 45 percent of private sector defined benefit plans provided some post-retirement cost of living increase, usually ad hoc. We have indexed Social Security, Military pension, Railroad retirement, and all government employee pension annuities at an annual rate of 4 percent. Other annuities are not indexed.

3. See Venti and Wise [1989, 1990a, 1991], Feinstein and McFadden [1989], and Sheiner and Weil [1992].

4. The value for 1991 may be an anomaly. Medians in earlier years were about $\$ 9,000$ and mean values increased from about $\$ 34,365$ in 1984 to $\$ 42,018$ in 1991.

5. See EBRI [1986].

6. The data show an anomalous increase from 25.5 in 1988 to 34.0 in 1989. Preliminary tabulations by the Department of Labor show a decline to below 25.5 in 1990 .

7. There are three principle conceptual differences between the FOF and the NIPA definitions of savings. These involve treatment of non-housing durable goods, state and local government 
pension reserves, and net saving of corporate farms. For details see Wilson et al [1989].

8. Only persons with reported Social Security benefits are included in the analysis. 


\section{References}

Avery, Robert B., Gregory E. Elliehausen, and Thomas A. Gustafson. 1986. "Pensions and Social Security in Household Portfolios: Evidence from the 1983 Survey of Consumer Finances," in F. Adams and S. Wachter (eds.), Savings and Capital Formation. Lexington books.

Bernheim, B. Douglas. 1987. "The Economic Effects of Social Security." Journal of Public Economics, vol. 33, pp. 273-304.

Bernheim, B. Douglas and John Karl Scholz. 1993. "Private Saving and Public Policy." Tax Policy and the Economy, vol. 7, pp. 73-110.

Bernheim, B. Douglas, and John B. Shoven. 1988. "Pension Funding and Saving," in Z. Bodie, J. Shoven, and D. Wise (eds.), Pensions in the U.S. Economy. University of Chicago Press.

Blinder, Alan S., Roger Gordon, and David E. Wise. 1981. An Empirical Study of the Effects of Pensions on the Saving and Labor Supply Decisions of Older Men. Princeton, NJ: Mathtech Inc.

Cagan, Phillip. 1965. The Effect of Pension Plans on Aggregate Saving: Evidence From a Sample Survey. Occasional Papers No. 95. National Bureau of Economic Research.

Diamond, Peter A. and Jerry A. Hausman. 1984. "Individual Retirement and Savings Behavior," Journal of Public Economics, vol. 23, pp. 81-114.

Employee Benefit Research Institute. 1986. "Tax Reform and Employee Benefits." Issue Brief No. 59, October. 
Feenberg, Daniel, and Jonathan Skinner. 1989. "Sources of IRA Saving." Tax Policy and the Economy 3: 25-46.

Feinstein, Jonathan and Daniel McFadden. 1989. "The Dynamics of Housing Demand by the Elderly: Wealth, Cash Flow, and Demographic Effects," in D. Wise (ed.), The Economics of Aging. Chicago: University of Chicago Press.

Gale, William G. and John Karl Scholz. 1990. "IRAs and Household Saving." Mimeo, University of Wisconsin.

Gustman, Alan and Thomas Steinmeier. 1993. "Cost of Living Increases in Pensions," in Olivia Mitchell (ed.), As the Workforce Ages. Ithaca, NY: ILR Press.

Hoynes, Hilary and Daniel McFadden. 1993. "The Impact of Demographics on Housing and Non-Housing Wealth in the United States," unpublished, September.

Hubbard, R. Glenn. 1985. "Personal Taxation, Pension Wealth, and Portfolio Composition," Review of Economics and Statistics, vol. 67, no 1, February pp. 53-60.

Joines, Douglas H., and James G. Manegold. 1991. "IRAs and Saving: Evidence from a Panel of Taxpayers." University of Southern California working paper no. 90-9.

Katona, George. 1965. Private Pensions and Individual Saving. University of Michigan Press. Lumsdaine, Robin L. and David A. Wise. 1990. "Aging and Labor Force Participation: A Review of Trends and Explanations." NBER Working Paper \#3420, August. (Forthcoming in JCER-NBER conference volume, University of Chicago Press.)

Munnell, Alicia H. 1976. "Private Pensions and Saving: New Evidence," Journal of Political Economy, vol. 84, October, pp. 1013-1032. 
Phillips, Kristen. 1992. "State and Local Pension Benefits," in John A. Turner and Daniel J. Beller (eds.), Trends in Pensions 1992. Washington D.C.

Poterba, James M., Steven F. Venti, and David A. Wise. 1994. "401(k) Plans and Tax-Deferred Saving," in D. Wise (ed.), Studies in the Economics of Aging, University of Chicago Press: 105-138. . 1995a. "Do 401(k) Contributions Crowd Out Other Personal Saving?" Journal of Public Economics 58: 1-32. . 1995b. "The Effects of Special Saving Programs on Saving and Wealth." NBER Working Paper No. 5287, October. 1996. "Do Retirement Saving Programs Increase Saving: Reconciling the Evidence." Working Paper, April.

Schieber, Sylvester and John Shoven. 1993. "The Consequences of Population Aging on Private Pension Fund Saving and Asset Markets," unpublished, September.

Sheiner, Louise and David N. Weil. 1992. "The Housing Wealth of the Aged," NBER Working Paper No. 4115, July.

Skinner, Jonathan. 1991. "Housing and Saving in the United States," NBER Working Paper No. 3874, October.

Venti, Steven F. and David A. Wise. 1986. "Tax-Deferred Accounts, Constrained Choice and Estimation of Individual Saving." Review of Economic Studies 53: 579-601. . 1987. "IRAs and Saving," in M. Feldstein (ed.), The Effects of Taxation on Capital Accumulation. Chicago: University of Chicago Press. 
1989. "Aging, Moving, and Housing Wealth," in D. Wise (ed.), The

Economics of Aging. Chicago: University of Chicago Press.

. 1990a. "But They Don't Want To Reduce Housing Equity", in D. Wise

(ed.), Issues in the Economics of Aging. Chicago: University of Chicago Press.

. 1990b. "Have IRAs Increased U.S. Saving?: Evidence from the Consumer

Expenditure Surveys." Quarterly Journal of Economics 105: 661-698.

. 1991. "Aging and the Income Value of Housing Wealth." Journal of Public

Economics, 44:371-395.

. 1992. "Government Policy and Personal Retirement Saving." Tax Policy

and the Economy 6:1-41.

Wilson, John F., James L. Freund, Frederick O. Yohn, and Walter Lederer. 1989. "Measuring Household Saving: Recent Experience from the Flow-of-Funds Perspective," in R. Lipsey and H. Tice (eds.), The Measurement of Saving, Investment, and Wealth. Chicago: University of Chicago Press. 
Figure 1a. Median Assets by Year

Families Aged 65-69

Figure 1b. Mean Assets by Year

Families Aged 65-69

Figure 1c. Mean Wealth Increase 1984-1991

Families Aged 65-69

Figure 2. IRA and 401(k) Contributions

Figure 3a. Retirement Plan Contributions

Figure 3b. National Flow of Funds Saving

Figure 4a. Illustration of Cohort Data

Personal Retirement Assets

Figure 4b. Illustration of Cohort Data

Personal Retirement Assets-Fitted

Figure 5a. Personal Retirement Assets

All Respondents-Five Cohorts-Means

Figure 5b. Other Personal Financial Assets

All Respondents-Five Cohorts-Means

Figure 5c. Total Personal Financial Assets

All Respondents-Five Cohorts-Means

Figure 5d. Total PFA vs. PRA

All Respondents, Selected Cohorts 
Figure 5e. Personal Financial Assets, Total and Retirement Means-All Respondents-Indexed

Figure 5f. Personal Financial Assets, Other Means-All Respondents-Indexed

Figure 5g. Total Personal Financial Assets Means-Both-Actual and Projected

Figure 6a. Personal Financial Assets, Total and Retirement Means-Contributors-Indexed

Figure 6b. Personal Financial Assets, Other Means-Contributors-Indexed

Figure 6c. Personal Financial Assets, Other Means-Non-Contributors-Indexed

Figure 6d. Total Personal Financial Assets Means-Contributors-Actual and Projected

Figure 7a. Personal Financial Assets, Total and Retirement Medians-Contributors-Indexed

Figure 7b. Personal Financial Assets, Other Medians-Contributors-Indexed

Figure 7c. Personal Financial Assets, Other Medians-Non-Contributors-Indexed

Figure 7d. Total Personal Financial Assets Medians-Contributors-Actual and Projected

Figure 8. Home Equity All Respondents-Selected Cohorts-Indexed 


\begin{tabular}{|c|c|c|c|c|c|c|}
\hline \multirow{2}{*}{ Cohort } & \multicolumn{2}{|c|}{$\begin{array}{c}\text { Personal Retirement } \\
\text { Assets }\end{array}$} & \multicolumn{2}{|c|}{$\begin{array}{c}\text { Total Personal Financial } \\
\text { Assets }\end{array}$} & \multicolumn{2}{|c|}{$\begin{array}{c}\text { Other Personal Financial } \\
\text { Assets }\end{array}$} \\
\hline & Coefficient & t-Stat & Coefficient & t-Stat & Coefficient & t-Stat \\
\hline \multicolumn{7}{|c|}{ a. Both Contributors and Non-Contributors -- Means } \\
\hline $\mathrm{C} 42$ & 14076 & 19.0 & 16002 & 8.2 & 1927 & 1.0 \\
\hline C44 & 11085 & 17.9 & 12024 & 7.3 & 939 & 0.6 \\
\hline $\mathrm{C} 46$ & 9997 & 17.3 & 9568 & 6.3 & -428 & -0.3 \\
\hline $\mathrm{C} 48$ & 7821 & 14.8 & 6556 & 4.7 & -1264 & -0.9 \\
\hline $\mathrm{C} 50$ & 5759 & 11.9 & 4132 & 3.2 & -1626 & -1.3 \\
\hline C52 & 3814 & 8.6 & 1459 & 1.2 & -2354 & -2.1 \\
\hline C54 & 1944 & 4.7 & 452 & 0.4 & -1492 & -1.4 \\
\hline $\mathrm{C} 56$ & 363 & 0.9 & 734 & 0.7 & 370 & 0.4 \\
\hline C58 & -1604 & -3.9 & -1682 & -1.6 & -78 & -0.1 \\
\hline $\mathrm{C} 60$ & -3815 & -8.7 & -5165 & -4.5 & -1349 & -1.2 \\
\hline $\mathrm{C} 62$ & -5813 & -12.1 & -3796 & -3.0 & 2017 & 1.7 \\
\hline C64 & -8130 & -15.4 & -5234 & -3.7 & 2895 & 2.2 \\
\hline C66 & -10345 & -18.0 & -8766 & -5.8 & 1578 & 1.1 \\
\hline C68 & -12049 & -19.2 & -12203 & -7.3 & -154 & -0.1 \\
\hline C70 & -13103 & & -14081 & & -981 & \\
\hline \multicolumn{7}{|c|}{ b. Contributors -- Means } \\
\hline $\mathrm{C} 42$ & 30138 & 16.3 & 31120 & 4.4 & 982 & 0.1 \\
\hline $\mathrm{C} 44$ & 24305 & 15.8 & 25331 & 4.3 & 1025 & 0.1 \\
\hline $\mathrm{C} 46$ & 21990 & 15.3 & 20567 & 3.8 & -1423 & 0.2 \\
\hline $\mathrm{C} 48$ & 17802 & 13.5 & 16136 & 3.2 & -1666 & -0.3 \\
\hline C50 & 13235 & 11.0 & 11451 & 2.5 & -1784 & -0.4 \\
\hline $\mathrm{C} 52$ & 8697 & 7.9 & 5686 & 1.3 & -3011 & -0.7 \\
\hline C54 & 4355 & 4.2 & 2536 & 0.6 & -1818 & -0.5 \\
\hline $\mathrm{C} 56$ & 381 & 0.4 & 379 & 0.1 & -2 & 0.0 \\
\hline C58 & -4140 & -4.1 & -5351 & -1.4 & -1210 & -0.3 \\
\hline $\mathrm{C} 60$ & -8972 & -8.2 & -15512 & -3.7 & -6539 & -1.6 \\
\hline C62 & -12970 & -10.8 & -10886 & -2.4 & 2084 & 0.5 \\
\hline C64 & -17496 & -13.3 & -10101 & -2.0 & 7395 & 1.5 \\
\hline C66 & -21873 & -15.3 & -11122 & -2.0 & 10751 & 2.0 \\
\hline C68 & -26299 & -16.8 & -24331 & -4.1 & 1968 & 0.3 \\
\hline $\mathrm{C} 70$ & -29153 & & -35903 & & -6752 & \\
\hline
\end{tabular}




\begin{tabular}{||l|c|c|c|c|c|c||}
\hline \multirow{2}{*}{ Table 1. Projection Equation Estimated Cohort Effects, by Asset and Contributor Status, } \\
Cont.
\end{tabular}




\begin{tabular}{|c|c|c|c|c|}
\hline \multirow{2}{*}{ Age Interval \& Data Reported } & \multicolumn{2}{|c|}{ Means } & \multicolumn{2}{|c|}{ Medians } \\
\hline & 1984 & 1991 & 1984 & 1991 \\
\hline \multicolumn{5}{|l|}{ Age 55 to 59} \\
\hline \multicolumn{5}{|l|}{ All Respondents } \\
\hline Personal Retirement Assets & 3456 & 9015 & -- & -- \\
\hline Other Personal Financial Assets & 19271 & 17052 & -- & -- \\
\hline Total Personal Financial Assets & 22729 & 26066 & -- & -- \\
\hline \multicolumn{5}{|l|}{ Contributors } \\
\hline \% With Personal Retirement Saving & 43 & 43 & 43 & 43 \\
\hline Personal Retirement Assets & 8215 & 21225 & 5561 & 11997 \\
\hline Other Personal Financial Assets & 31864 & 31028 & 11997 & 10581 \\
\hline Total Personal Financial Assets & 40081 & 52254 & 19878 & 28952 \\
\hline \multicolumn{5}{|l|}{ Non-Contributors } \\
\hline \% Without Personal Retirement Saving & 57 & 57 & 57 & 57 \\
\hline Total Personal Financial Assets & 9744 & 6590 & 1006 & 921 \\
\hline \multicolumn{5}{|l|}{ Age 60-64 } \\
\hline \multicolumn{5}{|l|}{ All Respondents } \\
\hline Personal Retirement Assets & 3946 & 10914 & -- & -- \\
\hline Other Personal Financial Assets & 28629 & 27959 & -- & -- \\
\hline Total Personal Financial Assets & 32575 & 38874 & -- & -- \\
\hline \multicolumn{5}{|l|}{ Contributors } \\
\hline \% With Personal Retirement Saving & 38 & 42 & 38 & 42 \\
\hline Personal Retirement Assets & 9968 & 25795 & 6300 & 17076 \\
\hline Other Personal Financial Assets & 51397 & 50160 & 17720 & 16598 \\
\hline Total Personal Financial Assets & 61365 & 75954 & 26996 & 38691 \\
\hline \multicolumn{5}{|l|}{ Non-Contributors } \\
\hline \% Without Personal Retirement Saving & 62 & 58 & 62 & 58 \\
\hline Total Personal Financial Assets & 13468 & 12684 & 2073 & 1645 \\
\hline
\end{tabular}




\begin{tabular}{|c|c|c|c|c|}
\hline \multirow{2}{*}{ Age Interval \& Data Reported } & \multicolumn{2}{|c|}{ Means } & \multicolumn{2}{|c|}{ Medians } \\
\hline & 1984 & 1991 & 1984 & 1991 \\
\hline \multicolumn{5}{|l|}{ Age 65-69 } \\
\hline \multicolumn{5}{|l|}{ All Respondents } \\
\hline Personal Retirement Assets & 2467 & 8022 & -- & -- \\
\hline Other Personal Financial Assets & 33352 & 29483 & - & -- \\
\hline Total Personal Financial Assets & 35819 & 37505 & -- & -- \\
\hline \multicolumn{5}{|l|}{ Contributors } \\
\hline \% With Personal Retirement Saving & 19 & 35 & 19 & 35 \\
\hline Personal Retirement Assets & 11925 & 24672 & 7245 & 14047 \\
\hline Other Personal Financial Assets & 62073 & 60753 & 31659 & 27762 \\
\hline Total Personal Financial Assets & 73998 & 85426 & 40948 & 53636 \\
\hline \multicolumn{5}{|l|}{ Non-Contributors } \\
\hline \% Without Personal Retirement Saving & 81 & 65 & 81 & 65 \\
\hline Total Personal Financial Assets & 22708 & 17152 & 9171 & 7446 \\
\hline \multicolumn{5}{|c|}{$\begin{array}{l}\text { Based on mean and median regressions controlling for age, education, marital status, and income. The } \\
\text { means for each age-saver group are evaluated at the } 1987 \text { means of the demogrphic variables for tha } \\
\text { group. The medians are evaluated at the } 1987 \text { medians of the demographic variables. All values are } \\
\text { in } 1984 \text { dollars. }\end{array}$} \\
\hline
\end{tabular}




\begin{tabular}{|c|c|c|c|c|c|c|}
\hline $\begin{array}{l}\text { SS Wealth } \\
\text { Percentile }\end{array}$ & \multicolumn{2}{|c|}{$\begin{array}{c}\text { Personal Retirement } \\
\text { Assets }\end{array}$} & \multicolumn{2}{|c|}{$\begin{array}{l}\text { Other Personal } \\
\text { Financial Assets }\end{array}$} & \multicolumn{2}{|c|}{$\begin{array}{c}\text { Total Personal } \\
\text { Financial Assets } \\
\end{array}$} \\
\hline $1 \mathrm{st}$ & -.021 & $(.010)$ & -.006 & $(.050)$ & -.027 & $(.053)$ \\
\hline 2nd & -.000 & $(.013)$ & .052 & $(.061)$ & .052 & $(.065)$ \\
\hline $3 \mathrm{rd}$ & -.005 & $(.015)$ & .125 & $(.073)$ & .120 & $(.078)$ \\
\hline 4th & .008 & $(.016)$ & -.003 & $(.077)$ & .005 & $(.082)$ \\
\hline 5th & .028 & $(.016)$ & .230 & $(.075)$ & .257 & $(.079)$ \\
\hline 6th & -.005 & $(.011)$ & .159 & $(.055)$ & .153 & $(.058)$ \\
\hline 7th & -.008 & $(.012)$ & .024 & $(.059)$ & .016 & $(.062)$ \\
\hline 8th & -.012 & $(.016)$ & -.112 & $(.078)$ & -.124 & $(.083)$ \\
\hline 9th & -.008 & $(.014)$ & .126 & $(.067)$ & .118 & $(.071)$ \\
\hline \multirow[t]{2}{*}{ 10th } & .006 & $(.010)$ & .045 & $(.048)$ & .052 & $(.051)$ \\
\hline & & & 1987 & & & \\
\hline 1st & .013 & $(.013)$ & .074 & $(.053)$ & .087 & $(.056)$ \\
\hline 2nd & -.001 & $(.015)$ & -.040 & $(.060)$ & -.041 & $(.064)$ \\
\hline $3 \mathrm{rd}$ & -.011 & $(.023)$ & .054 & $(.090)$ & .043 & $(.096)$ \\
\hline 4th & -.008 & $(.020)$ & -.086 & $(.078)$ & -.093 & $(.083)$ \\
\hline 5th & .000 & $(.017)$ & .173 & $(.068)$ & .174 & $(.073)$ \\
\hline 6th & .020 & $(.013)$ & .208 & $(.053)$ & .228 & $(.056)$ \\
\hline 7th & .002 & $(.010)$ & .009 & $(.041)$ & .012 & $(.043)$ \\
\hline 8th & .020 & $(.014)$ & .027 & $(.057)$ & .047 & $(.060)$ \\
\hline 9th & .005 & $(.018)$ & -.278 & $(.071)$ & -.274 & $(.075)$ \\
\hline \multirow[t]{2}{*}{ 10th } & -.032 & $(.013)$ & .278 & $(.052)$ & .246 & $(.056)$ \\
\hline & & & 1991 & & & \\
\hline $1 \mathrm{st}$ & .006 & $(.020)$ & .066 & $(.055)$ & .072 & $(.062)$ \\
\hline 2nd & -.003 & $(.042)$ & .003 & $(.116)$ & .000 & $(.131)$ \\
\hline $3 \mathrm{rd}$ & .105 & $(.039)$ & .087 & $(.107)$ & .192 & $(.121)$ \\
\hline 4th & .064 & $(.030)$ & .084 & $(.083)$ & .147 & $(.093)$ \\
\hline 5th & -.016 & $(.023)$ & -.023 & $(.064)$ & -.039 & $(.073)$ \\
\hline 6th & -.029 & $(.026)$ & .065 & $(.071)$ & .036 & $(.080)$ \\
\hline 7th & -.007 & $(.029)$ & -.007 & $(.080)$ & -.013 & $(.090)$ \\
\hline 8th & .054 & $(.028)$ & .111 & $(.078)$ & .165 & $(.088)$ \\
\hline 9th & .057 & $(.026)$ & .031 & $(.071)$ & .088 & $(.080)$ \\
\hline 10th & -.027 & $(.022)$ & .039 & $(.061)$ & .012 & $(.069)$ \\
\hline
\end{tabular}




\begin{tabular}{|c|c|c|c|}
\hline \multicolumn{4}{|c|}{$\begin{array}{l}\text { Appendix Table 1. Components of Asset Categories, Proportion of Families Owning, an } \\
\text { Mean and Median Levels, Age 65-69, 1991 }\end{array}$} \\
\hline Asset Category and Component & $\begin{array}{l}\text { Percent } \\
\text { Owning }\end{array}$ & Mean & Median \\
\hline Personal (Targetted) Retirement Assets & 34.5 & 10992 & 0 \\
\hline Individual Retirement Accounts (IRAs) & 30.8 & 7239 & 0 \\
\hline 401(k) Accounts & 3.8 & 617 & 0 \\
\hline Keogh Plans & 1.9 & 1439 & 0 \\
\hline Life Insurance and annuities & 3.0 & 1626 & 0 \\
\hline Other Personal Financial Assets & 84.8 & 42018 & 7428 \\
\hline Saving Accounts \& CDs & 72.2 & 19894 & 3600 \\
\hline Money Markets Funds, Bonds, \& Securities & 13.3 & 8007 & 0 \\
\hline Stocks \& Mutual Funds & 21.9 & 13219 & 0 \\
\hline U.S. Savings Bonds & 14.1 & 548 & 0 \\
\hline Non-Interest Bearing Checking Accounts & 38.4 & 351 & 0 \\
\hline Employer-Provided Pension Assets & 56.2 & 62305 & 16017 \\
\hline Pension & 34.6 & 23276 & 0 \\
\hline Railroad Retirement & 2.0 & 3483 & 0 \\
\hline Federal & 5.1 & 9767 & 0 \\
\hline State Government & 2.6 & 11550 & 0 \\
\hline Local Government & 2.8 & 3569 & 0 \\
\hline Military & 7.1 & 5251 & 0 \\
\hline Veterans & 5.2 & 3891 & 0 \\
\hline Other & 3.0 & 1517 & 0 \\
\hline Social Security Assets & 88.0 & 99682 & 99167 \\
\hline Home Equity & 75.3 & 64955 & 50000 \\
\hline Equity in Other Property & 81.8 & 33855 & 5992 \\
\hline Net Equity in Other Property & 13.2 & 7450 & 0 \\
\hline Motor Vehicle Equity & 80.6 & 6902 & 3950 \\
\hline Business Equity & 5.9 & 7180 & 0 \\
\hline Rental Property & 7.7 & 7961 & 0 \\
\hline Other Properties (vacation, commercial,...) & 1.4 & 369 & 0 \\
\hline Money Owed to Family & 2.6 & 685 & 0 \\
\hline Equity in Other Financial Investments & 3.5 & 2258 & 0 \\
\hline Money Owed to Family-Business/Property Sale & 2.7 & 1049 & 0 \\
\hline
\end{tabular}




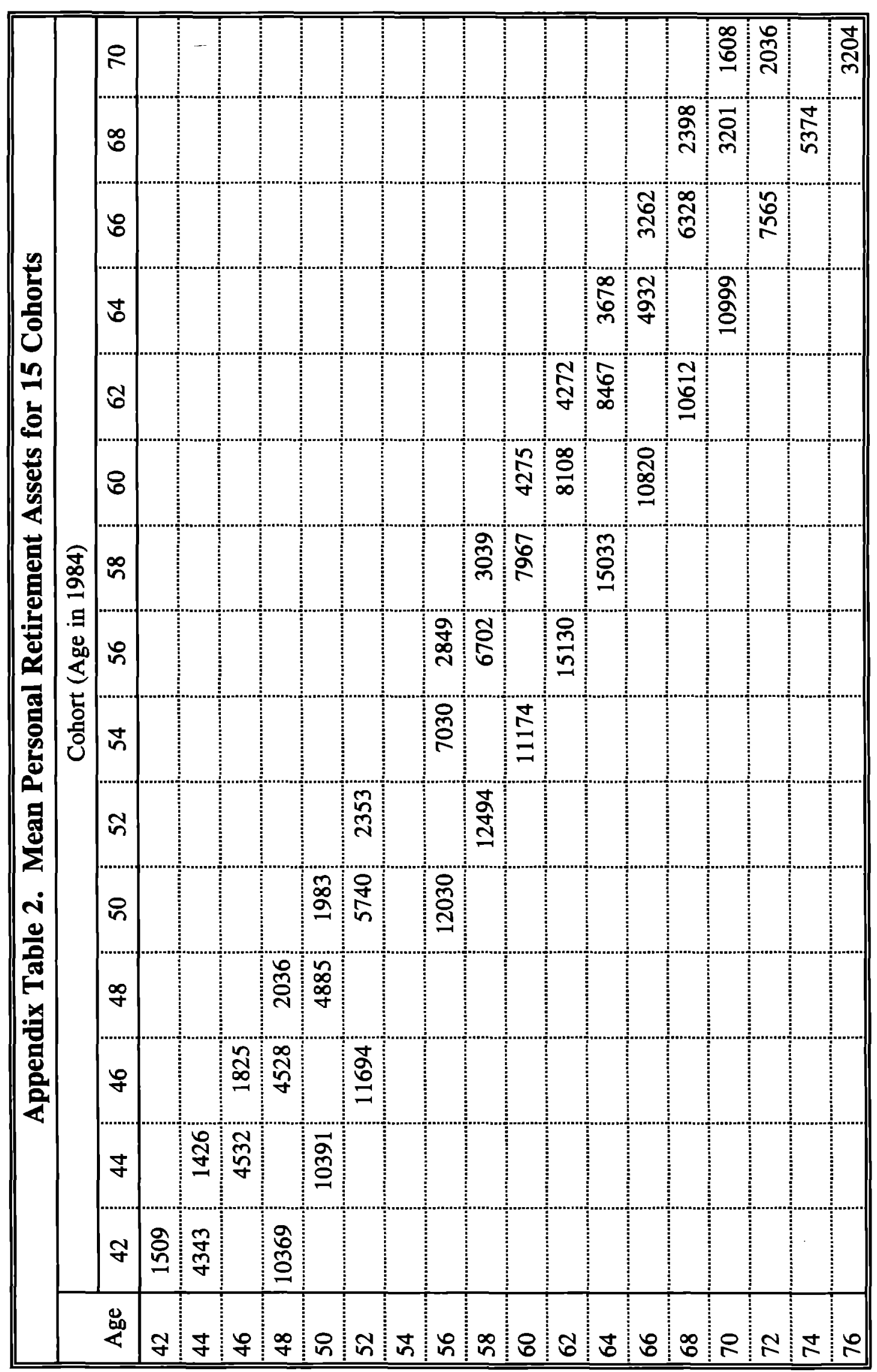




\begin{tabular}{|c|c|c|c|}
\hline \multicolumn{4}{|c|}{$\begin{array}{l}\text { Appendix Table 3a. Summary of Cohort Effects at Selected Age Intervals: Percents and } \\
\text { Conditional Means (1984 \$s) }\end{array}$} \\
\hline Age Interval \& Data Reported & 1984 & 1987 & 1991 \\
\hline \multicolumn{4}{|l|}{ Age 50 to 54} \\
\hline \multicolumn{4}{|l|}{ All Respondents } \\
\hline Personal Retirement Assets & 2772 & 5748 & 9103 \\
\hline Other Personal Financial Assets & 14456 & 14483 & 13501 \\
\hline Total Personal Financial Assets & 17227 & 20231 & 22604 \\
\hline \multicolumn{4}{|l|}{ Contributors } \\
\hline \% With Personal Retirement Saving & 36 & 42 & 46 \\
\hline Personal Retirement Assets & 7498 & 13767 & 20413 \\
\hline Other Personal Financial Assets & 27744 & 27511 & 24024 \\
\hline Total Personal Financial Assets & 35241 & 41277 & 44436 \\
\hline \multicolumn{4}{|l|}{ Non-Contributors } \\
\hline \% Without Personal Retirement Saving & 64 & 58 & 54 \\
\hline Total Personal Financial Assets & 6165 & 5145 & 5390 \\
\hline \multicolumn{4}{|l|}{ Age 55-59 } \\
\hline \multicolumn{4}{|l|}{ All Respondents } \\
\hline Personal Retirement Assets & 3456 & 6581 & 9015 \\
\hline Other Personal Financial Assets & 19271 & 18956 & 17052 \\
\hline Total Personal Financial Assets & 22729 & 25537 & 26066 \\
\hline \multicolumn{4}{|l|}{ Contributors } \\
\hline \% With Personal Retirement Saving & 43 & 43 & 43 \\
\hline Personal Retirement Assets & 8215 & 15325 & 21225 \\
\hline Other Personal Financial Assets & 31864 & 34953 & 31028 \\
\hline Total Personal Financial Assets & 40081 & 50279 & 52254 \\
\hline \multicolumn{4}{|l|}{ Non-Contributors } \\
\hline \% Without Personal Retirement Saving & 57 & 57 & 57 \\
\hline Total Personal Financial Assets & 9744 & 6916 & 6590 \\
\hline \multicolumn{4}{|l|}{ Age 60-64 } \\
\hline \multicolumn{4}{|l|}{ All Respondents } \\
\hline Personal Retirement Assets & 3946 & 6923 & 10914 \\
\hline Other Personal Financial Assets & 28629 & 25153 & 27959 \\
\hline Total Personal Financial Assets & 32575 & 32076 & 38874 \\
\hline
\end{tabular}




\begin{tabular}{|c|c|c|c|}
\hline \multicolumn{4}{|c|}{$\begin{array}{c}\text { Appendix Table 3a. Summary of Cohort Effects at Selected Age Intervals: Percents and } \\
\text { Conditional Means (1984 \$s) }\end{array}$} \\
\hline Age Interval \& Data Reported & 1984 & 1987 & 1991 \\
\hline \multicolumn{4}{|l|}{ Contributors } \\
\hline \% With Personal Retirement Saving & 38 & 41 & 42 \\
\hline Personal Retirement Assets & 9968 & 17042 & 25795 \\
\hline Other Personal Financial Assets & 51397 & 41179 & 50160 \\
\hline Total Personal Financial Assets & 61365 & 58220 & 75954 \\
\hline \multicolumn{4}{|l|}{ Non-Contributors } \\
\hline \% Without Personal Retirement Saving & 62 & 59 & 58 \\
\hline Total Personal Financial Assets & 13468 & 14189 & 12684 \\
\hline \multicolumn{4}{|l|}{ Age 65-69 } \\
\hline \multicolumn{4}{|l|}{ All Respondents } \\
\hline Personal Retirement Assets & 2467 & 4342 & 8022 \\
\hline Other Personal Financial Assets & 33352 & 31238 & 29483 \\
\hline Total Personal Financial Assets & 35819 & 35580 & 37505 \\
\hline \multicolumn{4}{|l|}{ Contributors } \\
\hline \% With Personal Retirement Saving & 19 & 27 & 35 \\
\hline Personal Retirement Assets & 11925 & 16037 & 24672 \\
\hline Other Personal Financial Assets & 62073 & 58129 & 60753 \\
\hline Total Personal Financial Assets & 73998 & 74166 & 85426 \\
\hline \multicolumn{4}{|l|}{ Non-Contributors } \\
\hline \% Without Personal Retirement Saving & 81 & 73 & 65 \\
\hline Total Personal Financial Assets & 22708 & 21253 & 17152 \\
\hline \multicolumn{4}{|l|}{ Age 70-74 } \\
\hline \multicolumn{4}{|l|}{ All Respondents } \\
\hline Personal Retirement Assets & 1626 & 1834 & 4433 \\
\hline Other Personal Financial Assets & 34291 & 34469 & 35680 \\
\hline Total Personal Financial Assets & 35917 & 36303 & 40112 \\
\hline \multicolumn{4}{|l|}{ Contributors } \\
\hline \% With Personal Retirement Saving & 8 & 15 & 20 \\
\hline Personal Retirement Assets & 14698 & 12594 & 22623 \\
\hline Other Personal Financial Assets & 88181 & 66427 & 89799 \\
\hline Total Personal Financial Assets & 102878 & 79020 & 112421 \\
\hline \multicolumn{4}{|l|}{ Non-Contributors } \\
\hline \% Without Personal Retirement Saving & 92 & 85 & 80 \\
\hline Total Personal Financial Assets & 26585 & 29020 & 25201 \\
\hline
\end{tabular}




\begin{tabular}{|c|c|c|c|}
\hline \multicolumn{4}{|c|}{$\begin{array}{c}\text { Appendix Table 3a. Summary of Cohort Effects at Selected Age Intervals: Percents and } \\
\text { Conditional Means (1984 \$s) }\end{array}$} \\
\hline Age Interval \& Data Reported & 1984 & 1987 & 1991 \\
\hline \multicolumn{4}{|l|}{ Age 75-79 } \\
\hline \multicolumn{4}{|l|}{ All Respondents } \\
\hline Personal Retirement Assets & 960 & 1082 & 1778 \\
\hline Other Personal Financial Assets & 30271 & 29241 & 33360 \\
\hline Total Personal Financial Assets & 31231 & 30323 & 35138 \\
\hline \multicolumn{4}{|l|}{ Contributors } \\
\hline \% With Personal Retirement Saving & 6 & 7 & 11 \\
\hline Personal Retirement Assets & 16305 & 16218 & 19187 \\
\hline Other Personal Financial Assets & 76484 & 75562 & 69867 \\
\hline Total Personal Financial Assets & 92789 & 91780 & 89054 \\
\hline \multicolumn{4}{|l|}{ Non-Contributors } \\
\hline \% Without Personal Retirement Saving & 94 & 93 & 89 \\
\hline Total Personal Financial Assets & 27025 & 25930 & 31141 \\
\hline \multicolumn{4}{|l|}{ Age $80+$} \\
\hline \multicolumn{4}{|l|}{ All Respondents } \\
\hline Personal Retirement Assets & 431 & 575 & 1243 \\
\hline Other Personal Financial Assets & 27493 & 27949 & 29880 \\
\hline Total Personal Financial Assets & 27924 & 28524 & 31123 \\
\hline \multicolumn{4}{|l|}{ Contributors } \\
\hline \% With Personal Retirement Saving & 4 & 4 & 5 \\
\hline Personal Retirement Assets & 8551 & 15288 & 25500 \\
\hline Other Personal Financial Assets & 78271 & 54771 & 76091 \\
\hline Total Personal Financial Assets & 86812 & 70059 & 101591 \\
\hline \multicolumn{4}{|l|}{ Non-Contributors } \\
\hline \% Without Personal Retirement Saving & 96 & 96 & 95 \\
\hline Total Personal Financial Assets & 25166 & 26900 & 27656 \\
\hline \multicolumn{4}{|c|}{$\begin{array}{l}\text { Based on mean regressions controlling for age, education, marital status, and income. The means for } \\
\text { each age-saver group are evaluated at the } 1987 \text { means of the demogrphic variables for that group. } \\
\text { All values are in } 1984 \text { dollars. }\end{array}$} \\
\hline
\end{tabular}




\begin{tabular}{|c|c|c|c|}
\hline \multicolumn{4}{|c|}{$\begin{array}{c}\text { Appendix Table 3b. Summary of Cohort Effects at Selected Age Intervals: Percents anc } \\
\text { Conditional Medians (1984 \$s) }\end{array}$} \\
\hline Age Interval \& Data Reported & 1984 & 1987 & 1991 \\
\hline \multicolumn{4}{|l|}{ Age 50 to 54} \\
\hline \multicolumn{4}{|l|}{ Contributors } \\
\hline \% With Personal Retirement Saving & 36 & 42 & 46 \\
\hline Personal Retirement Assets & 5374 & 8828 & 11542 \\
\hline Other Personal Financial Assets & 8851 & 8806 & 7701 \\
\hline Total Personal Financial Assets & 16392 & 20792 & 22883 \\
\hline \multicolumn{4}{|l|}{ Non-Contributors } \\
\hline$\%$ Without Personal Retirement Saving & 64 & 58 & 54 \\
\hline Total Personal Financial Assets & 831 & 829 & 721 \\
\hline \multicolumn{4}{|l|}{ Age 55-59 } \\
\hline \multicolumn{4}{|l|}{ Contributors } \\
\hline \% With Personal Retirement Saving & 43 & 43 & 43 \\
\hline Personal Retirement Assets & 5561 & 10051 & 11997 \\
\hline Other Personal Financial Assets & 11997 & 13274 & 10581 \\
\hline Total Personal Financial Assets & 19878 & 26918 & 28952 \\
\hline \multicolumn{4}{|l|}{ Non-Contributors } \\
\hline \% Without Personal Retirement Saving & 57 & 57 & 57 \\
\hline Total Personal Financial Assets & 1006 & 951 & 921 \\
\hline \multicolumn{4}{|l|}{ Age 60-64 } \\
\hline \multicolumn{4}{|l|}{ Contributors } \\
\hline$\%$ With Personal Retirement Saving & 38 & 41 & 42 \\
\hline Personal Retirement Assets & 6300 & 10954 & 17076 \\
\hline Other Personal Financial Assets & 17720 & 16800 & 16598 \\
\hline Total Personal Financial Assets & 26996 & 30832 & 38691 \\
\hline \multicolumn{4}{|l|}{ Non-Contributors } \\
\hline \% Without Personal Retirement Saving & 62 & 59 & 58 \\
\hline Total Personal Financial Assets & 2073 & 1834 & 1645 \\
\hline \multicolumn{4}{|l|}{ Age $65-69$} \\
\hline \multicolumn{4}{|l|}{ Contributors } \\
\hline$\%$ With Personal Retirement Saving & 19 & 27 & 35 \\
\hline Personal Retirement Assets & 7245 & 10420 & 14047 \\
\hline Other Personal Financial Assets & 31659 & 32493 & 27762 \\
\hline Total Personal Financial Assets & 40948 & 49222 & 53636 \\
\hline
\end{tabular}




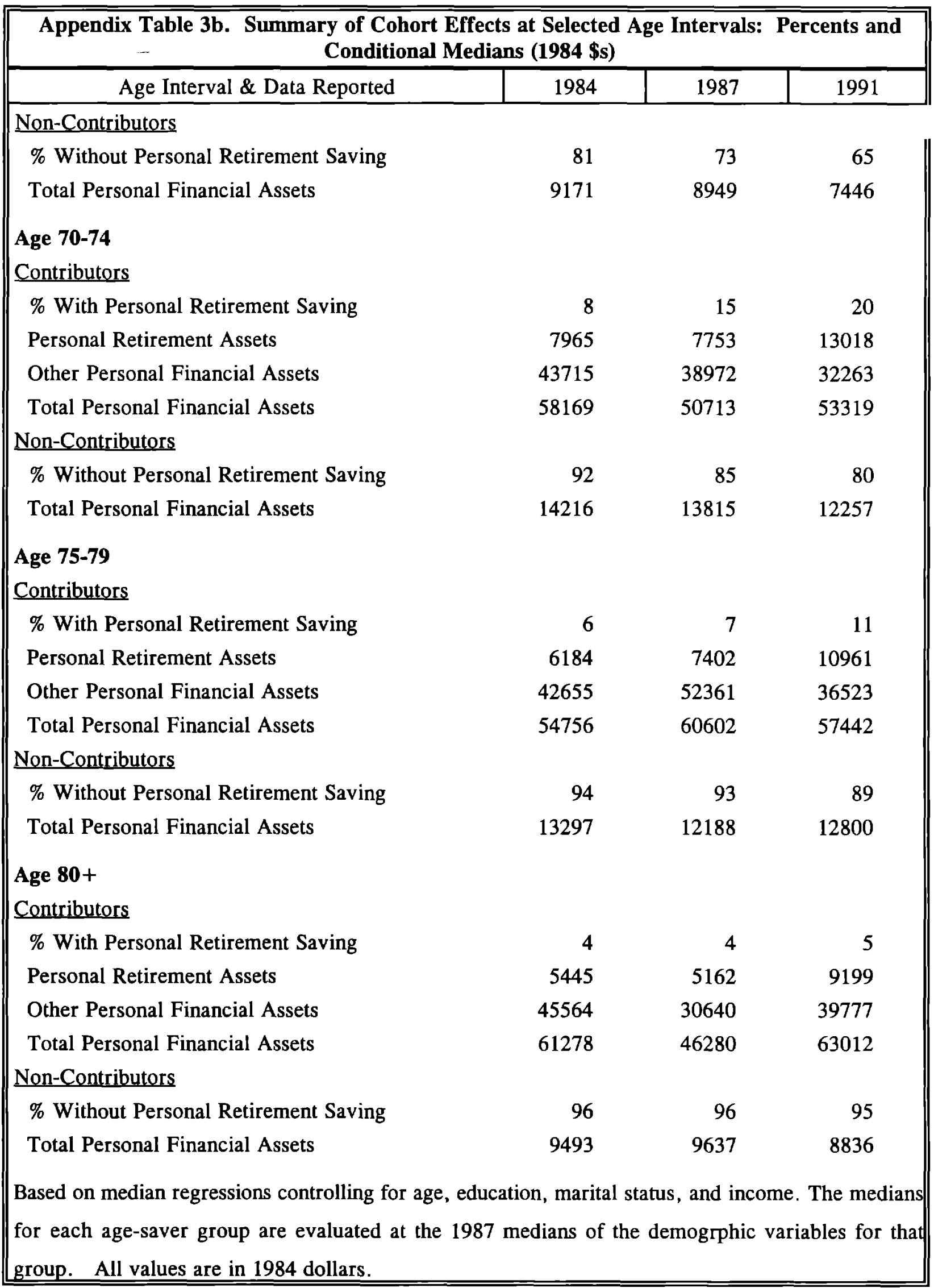


Fig 1a. Median Assets by Year Families Aged 65 to 69

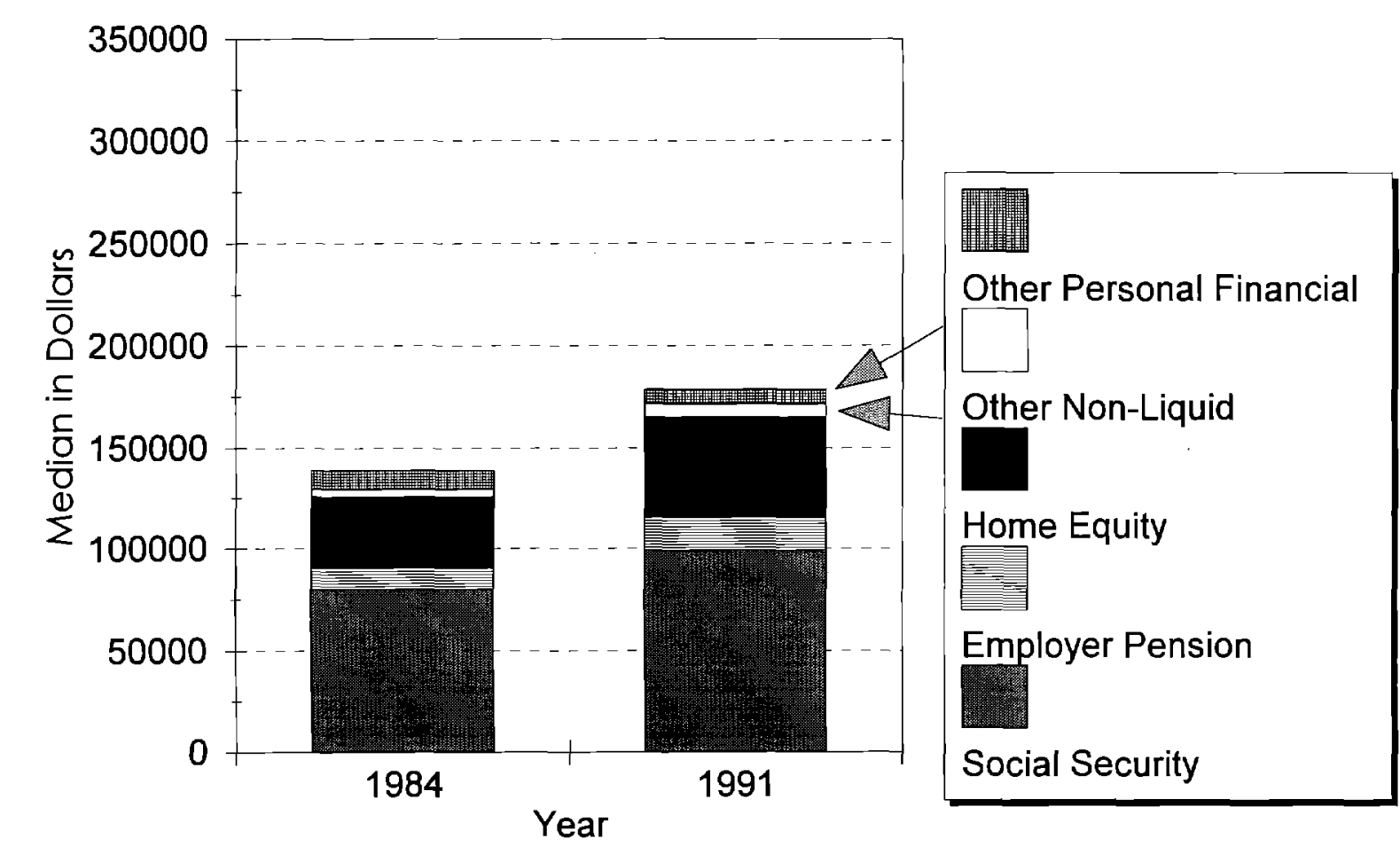




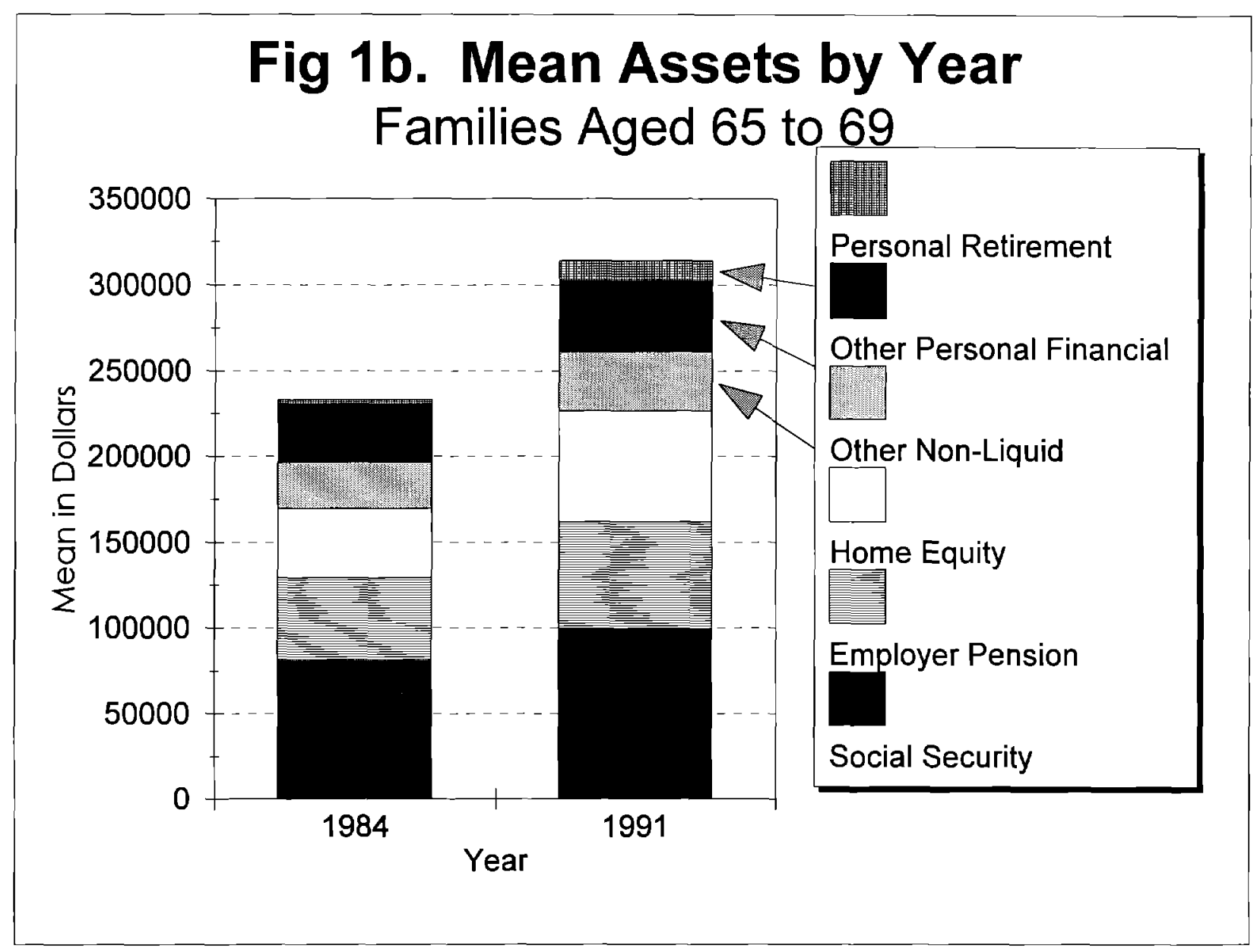


Fig 1c. Mean Wealth Increase 1984-91 Families 65-69

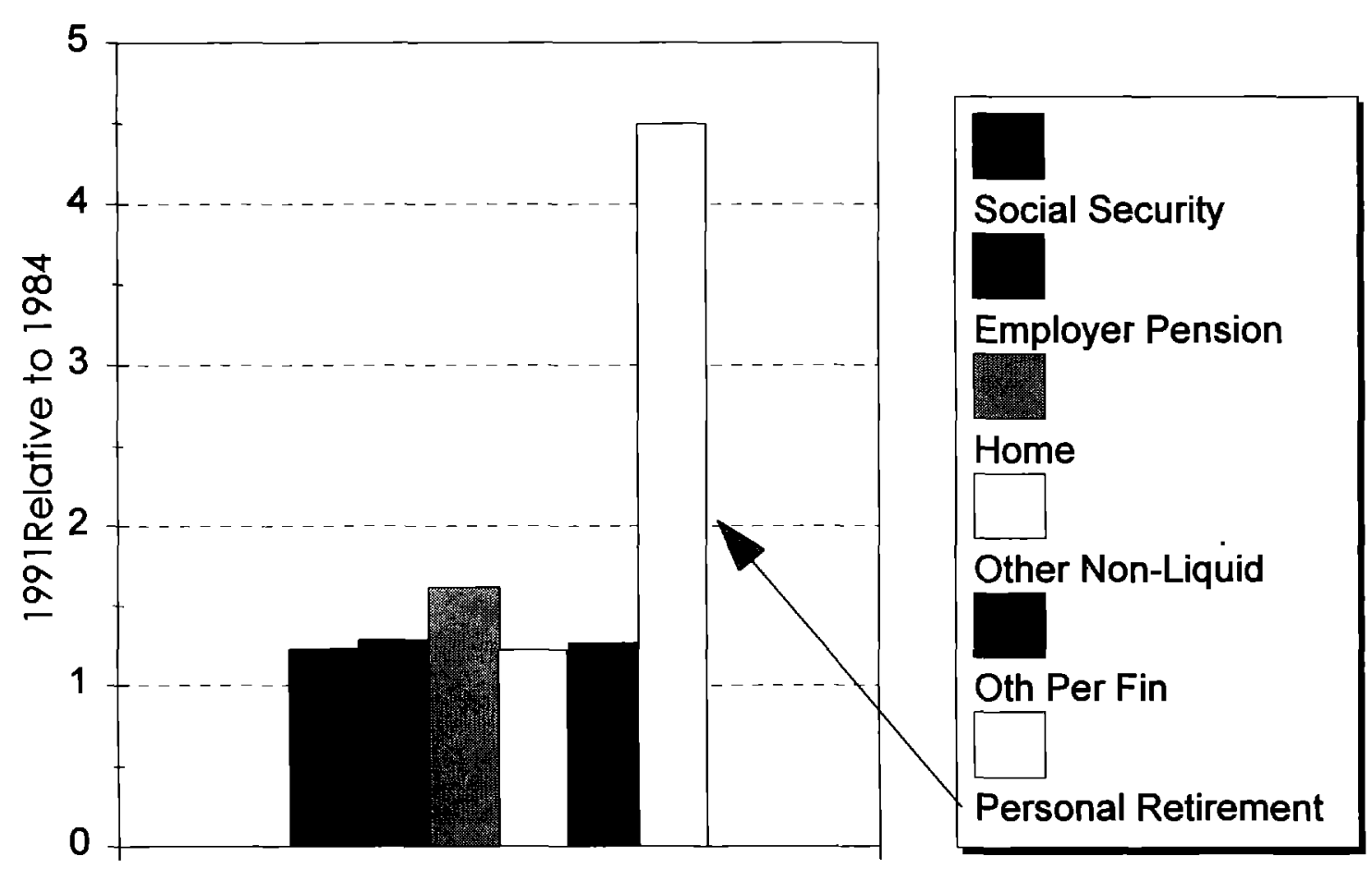




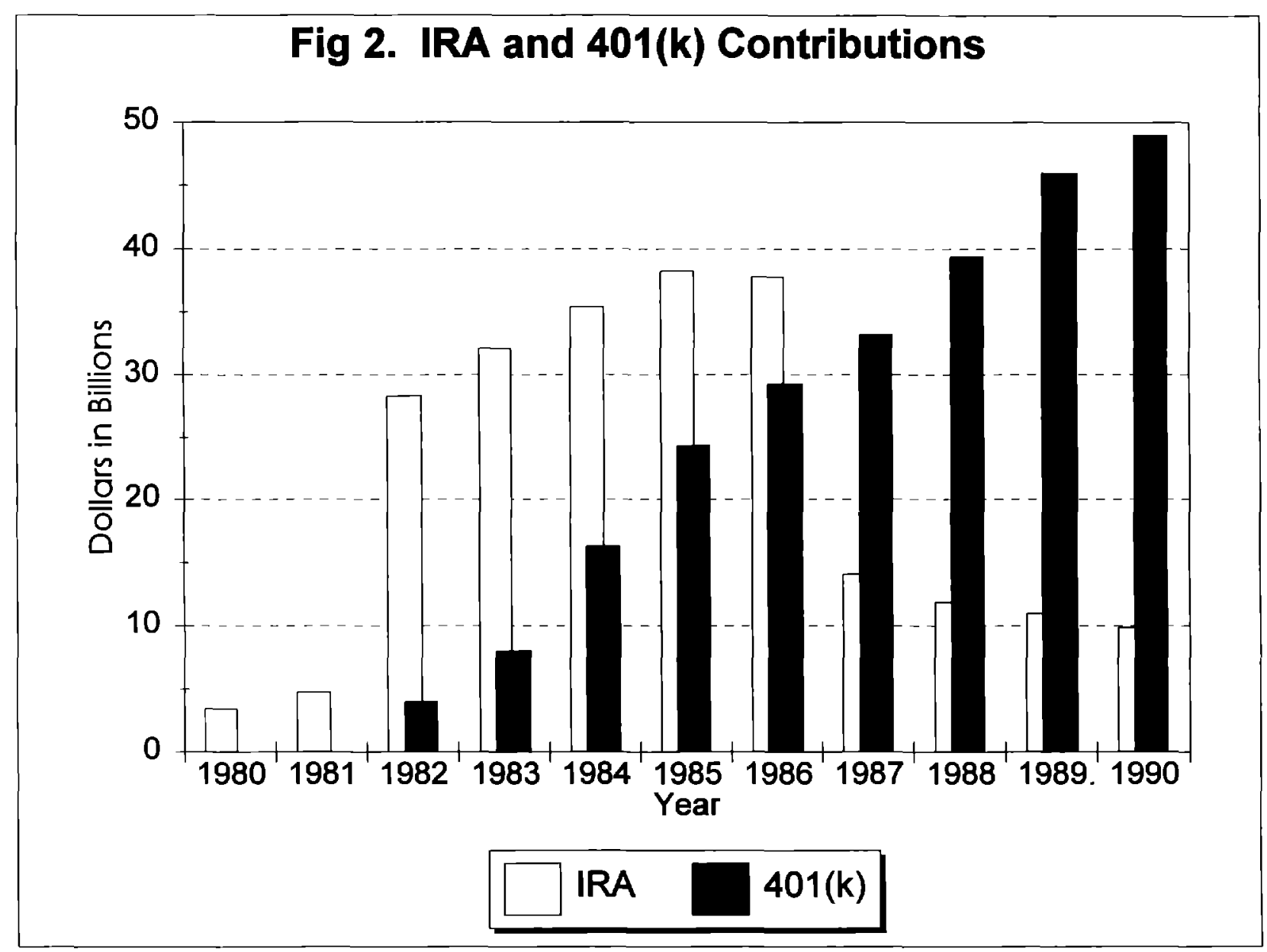




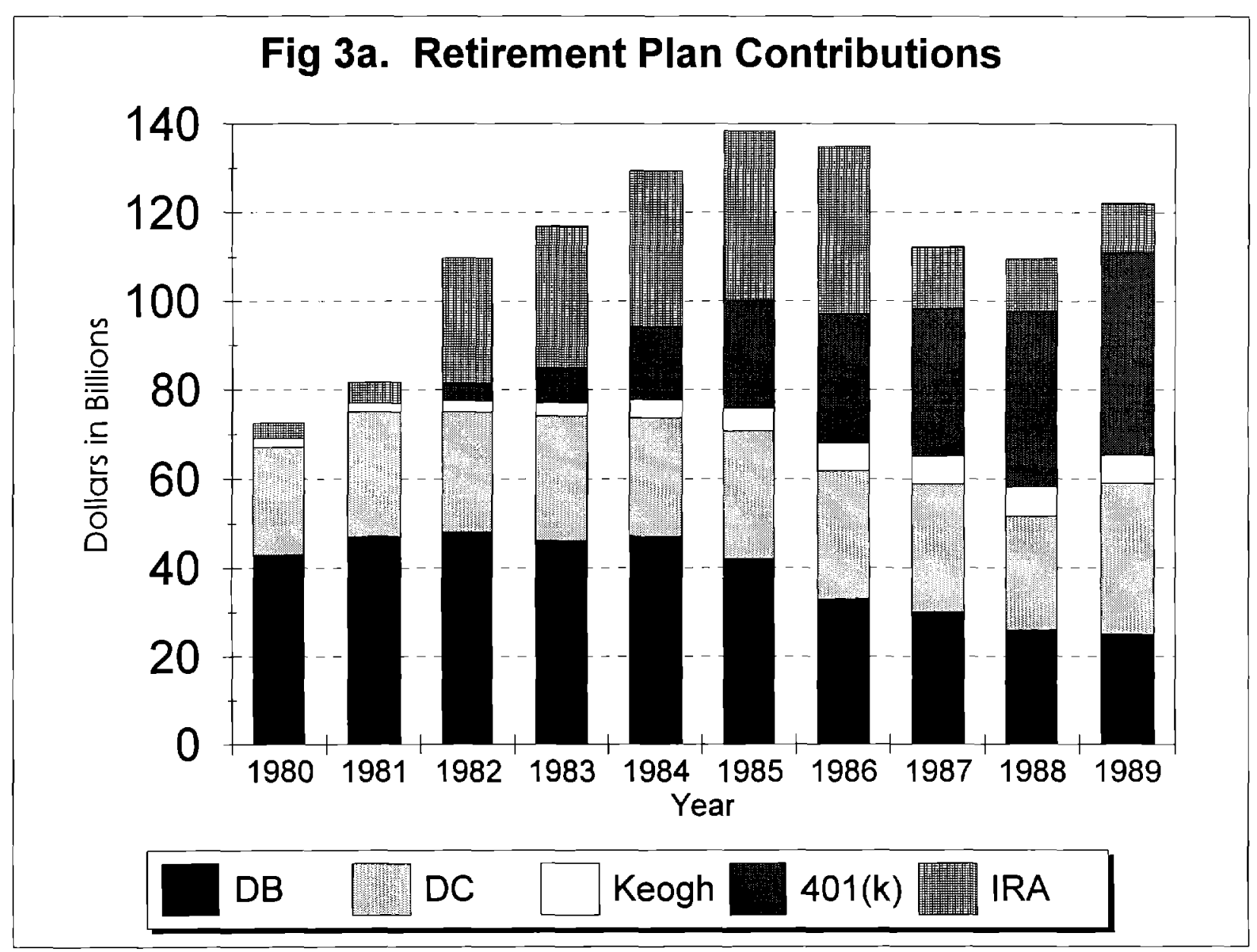


Fig 3b. National Flow of Funds Saving

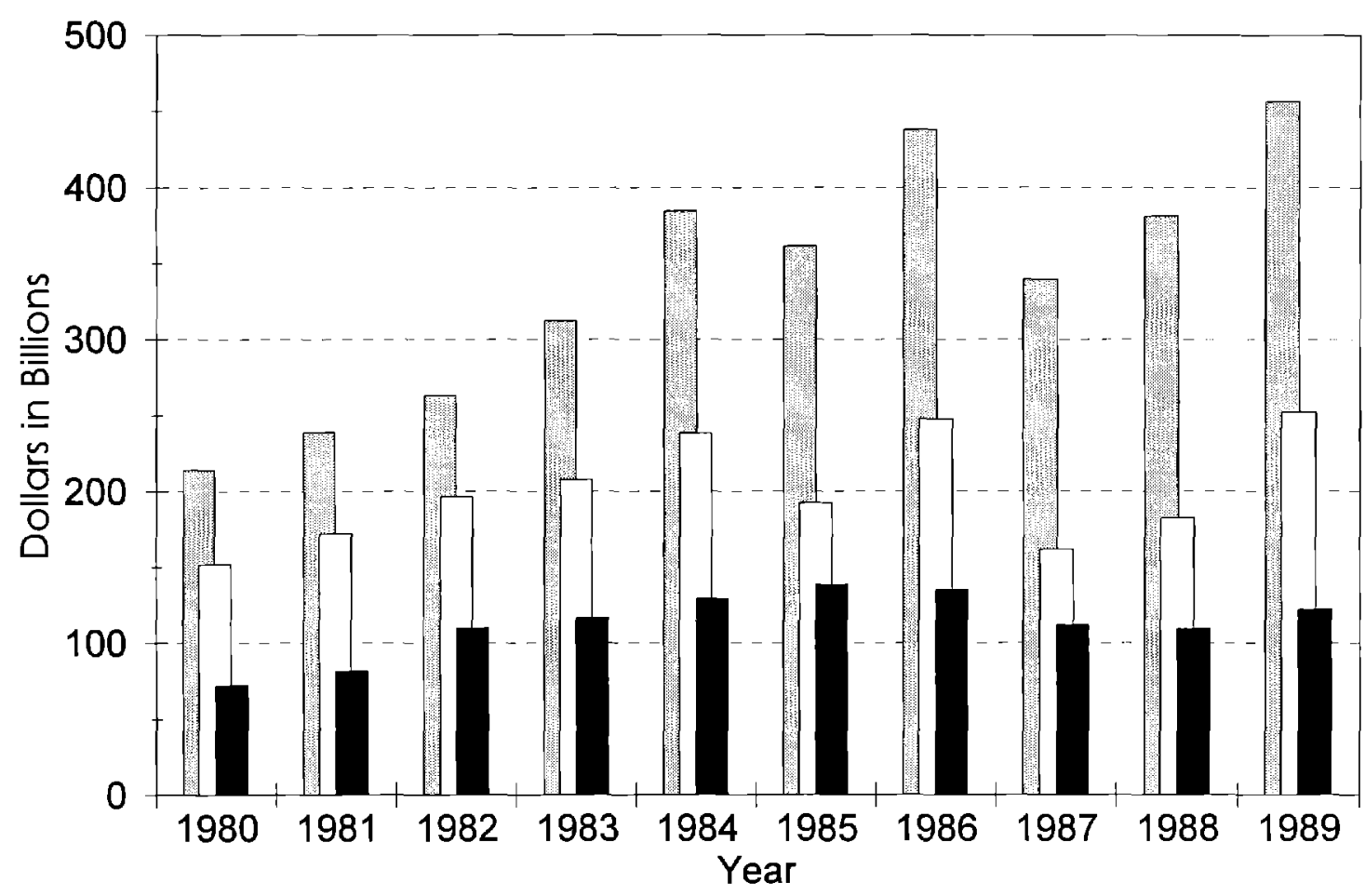




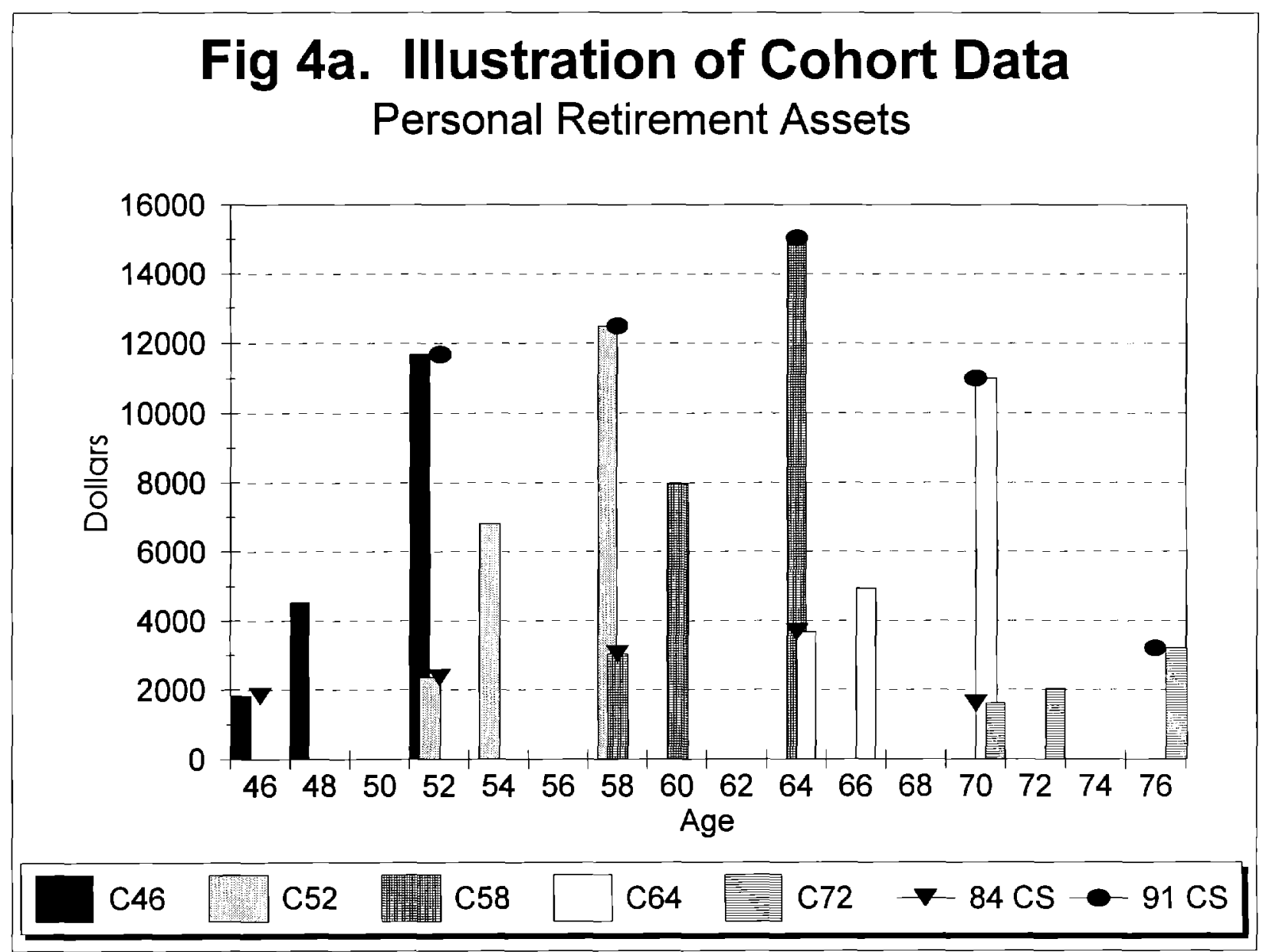


Fig 4b. Illustration of Cohort Data

Personal Retirement Assets--Fitted

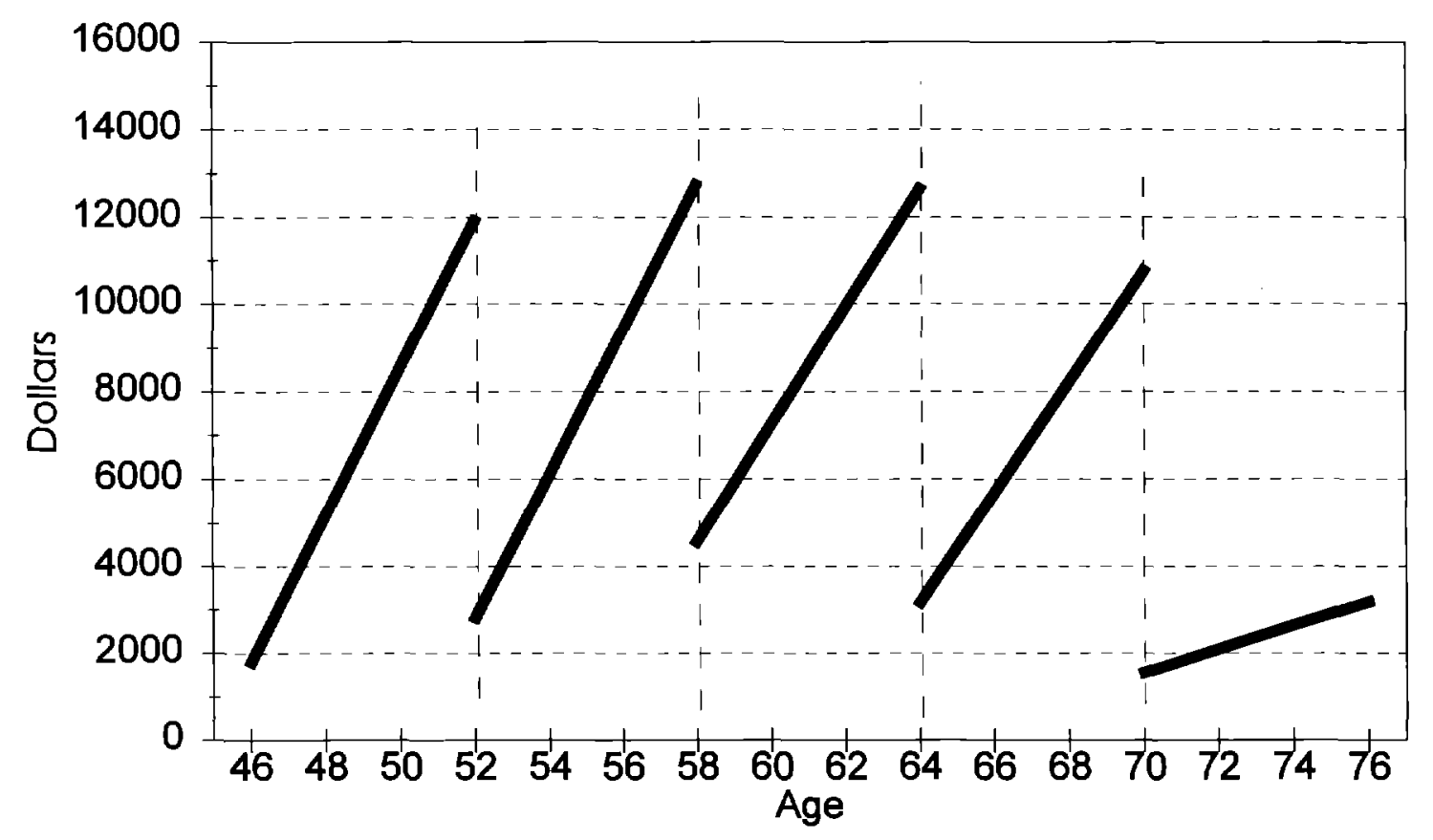

$$
-\mathrm{C} 46-\mathrm{C} 52-\mathrm{C} 58-\mathrm{C} 64-\mathrm{C} 72
$$




\section{Fig 5a. Personal Retirement Assets}

\section{All Respondents--Five Cohorts--Means}

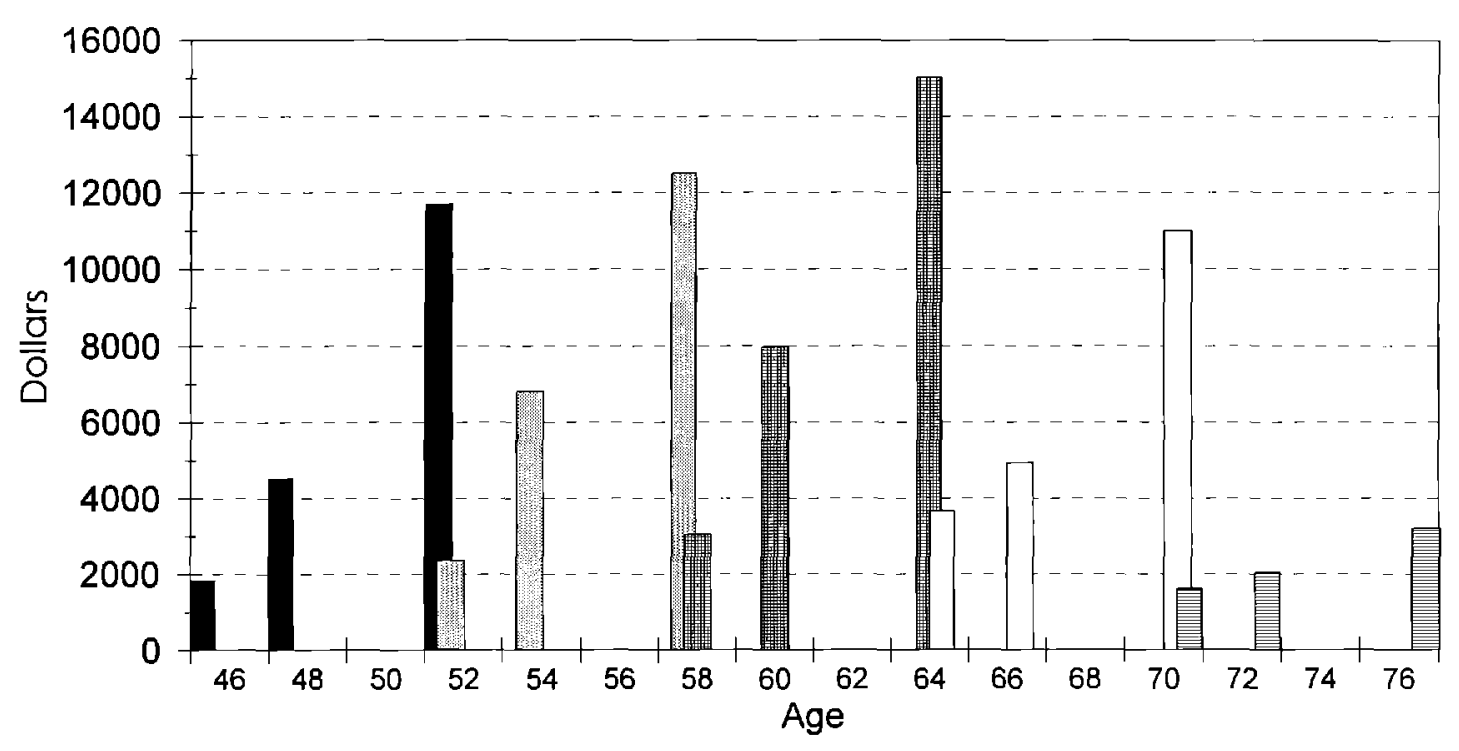

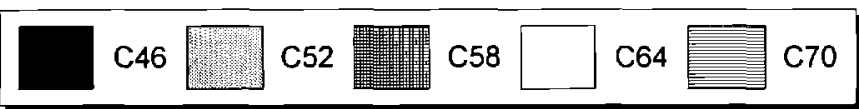




\section{Fig 5b. Other Personal Fin Assets All Respondents--Five Cohorts--Means}

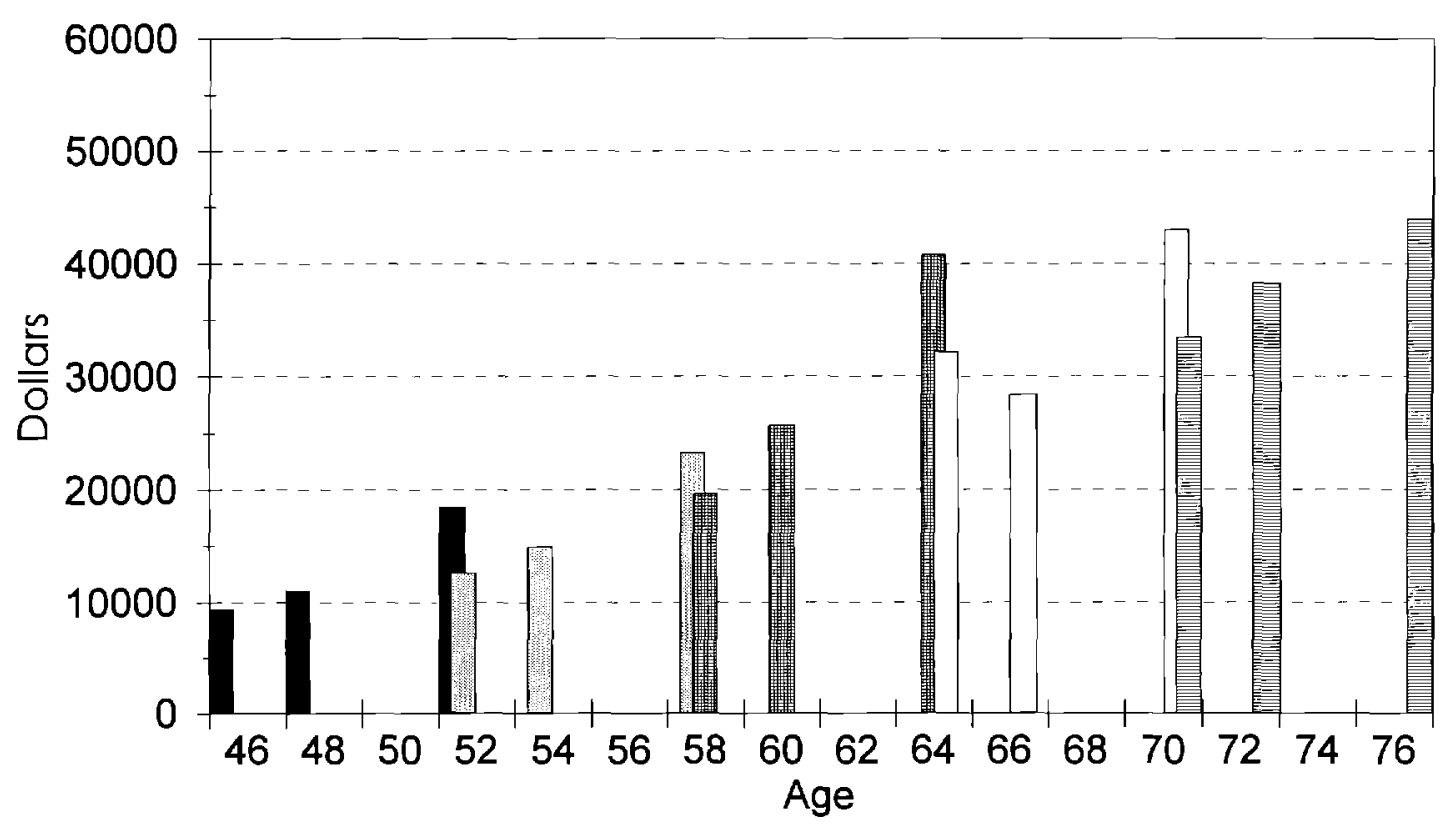

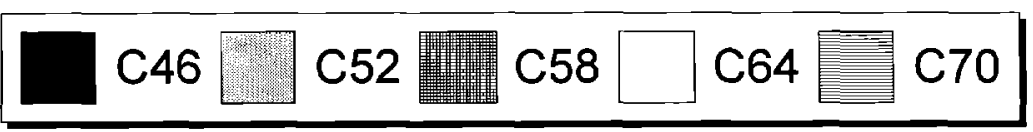




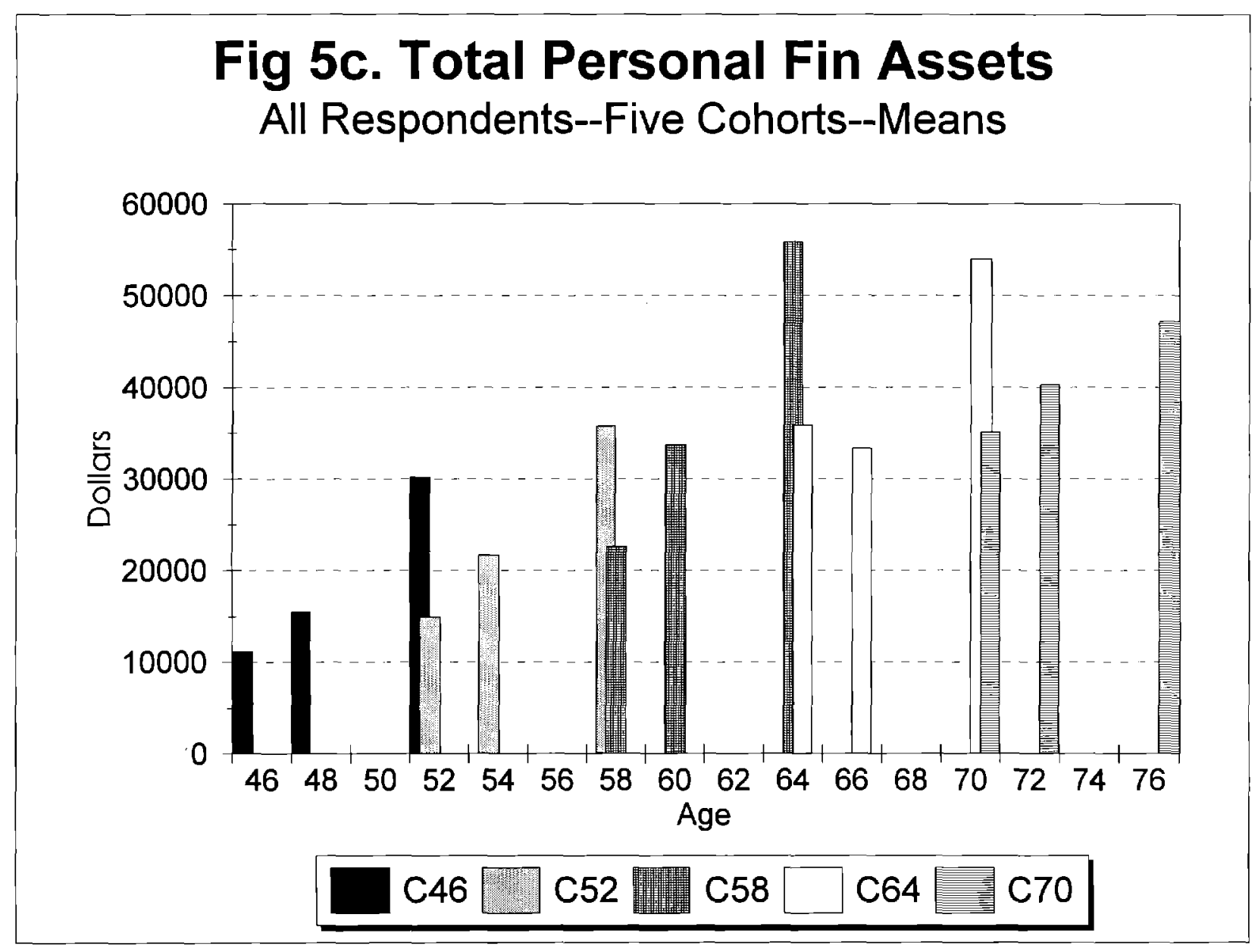




\section{Fig 5d. Total PFA v PRA}

All Respondents--Selected Cohorts

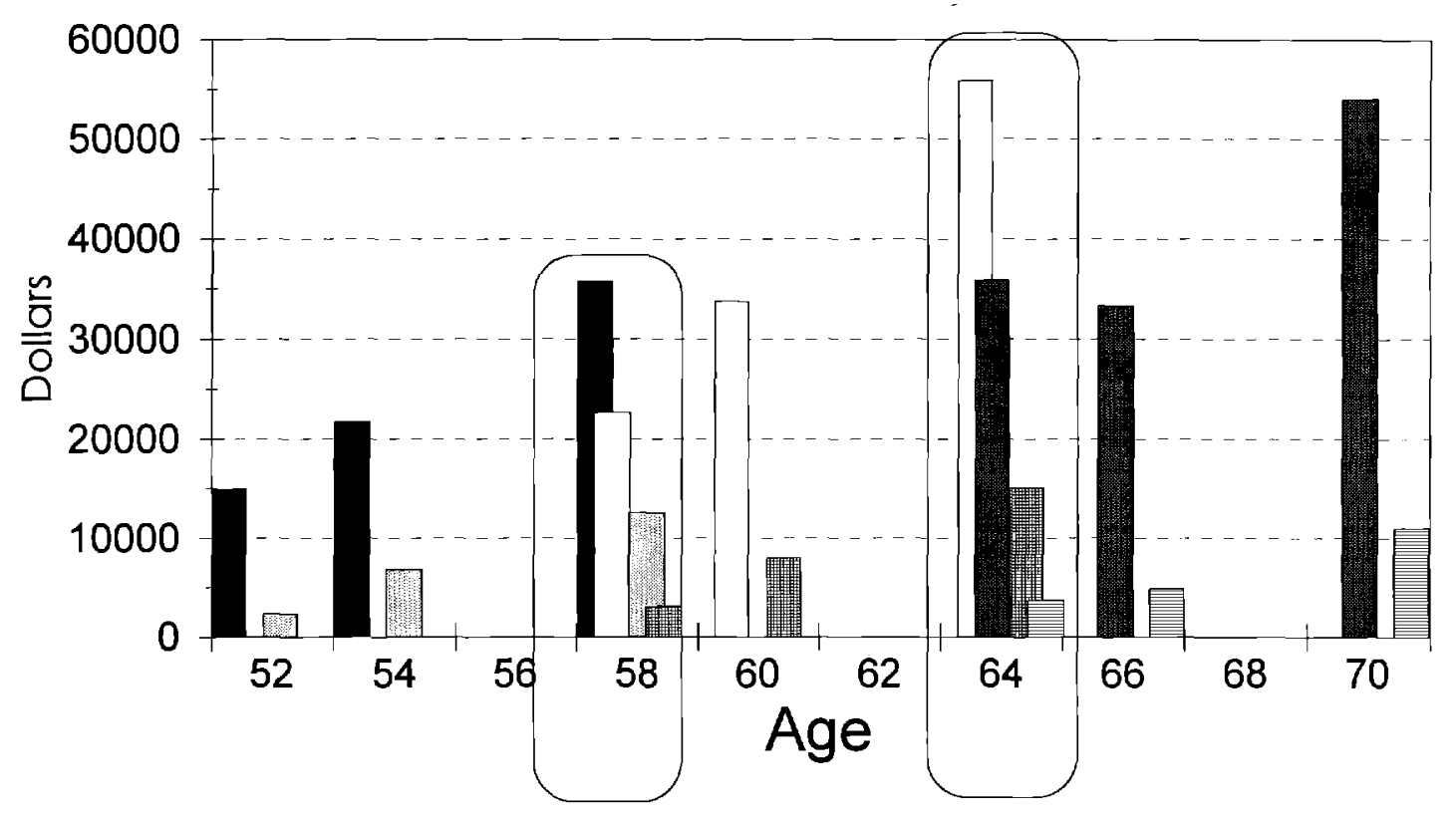




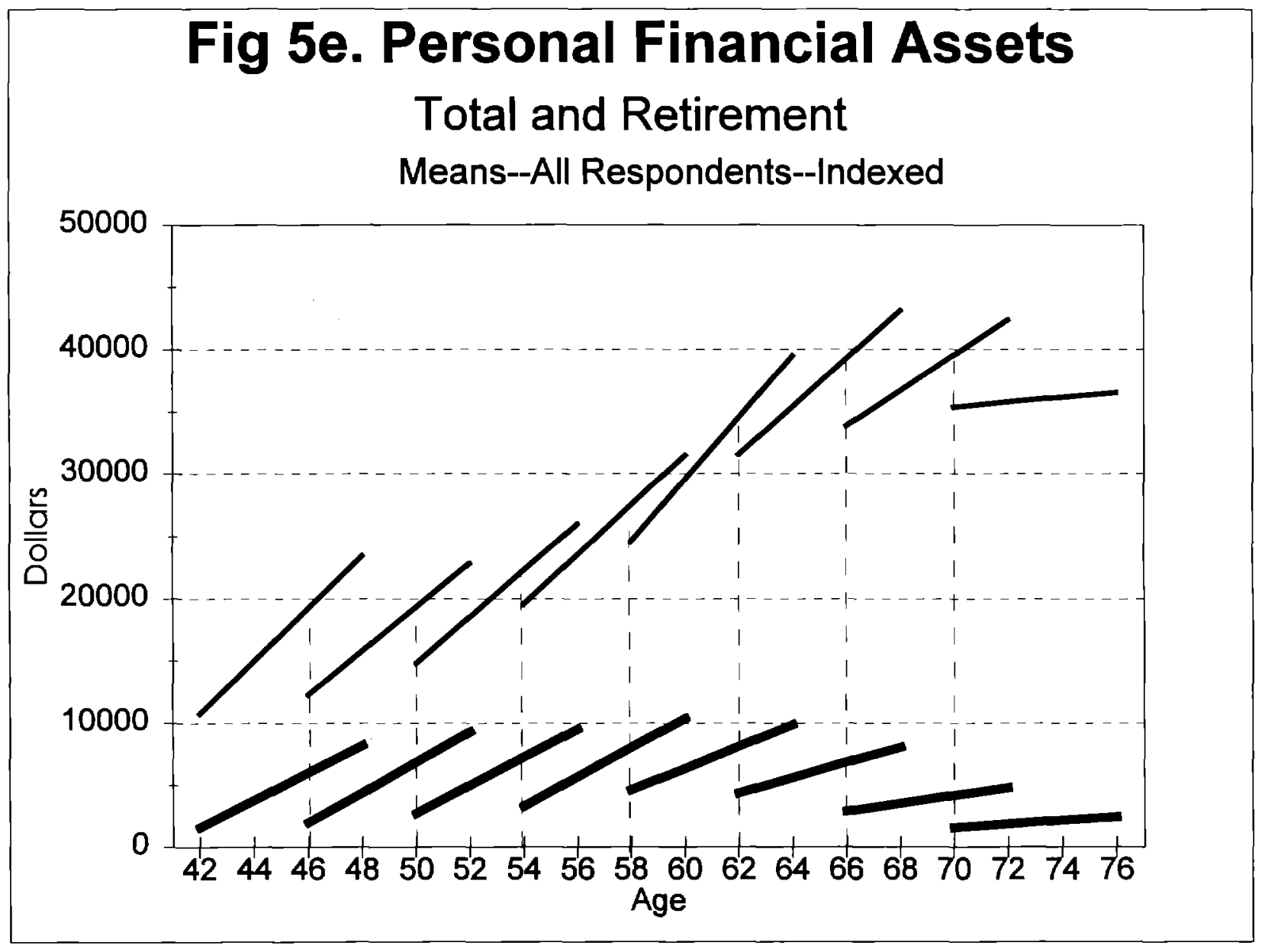




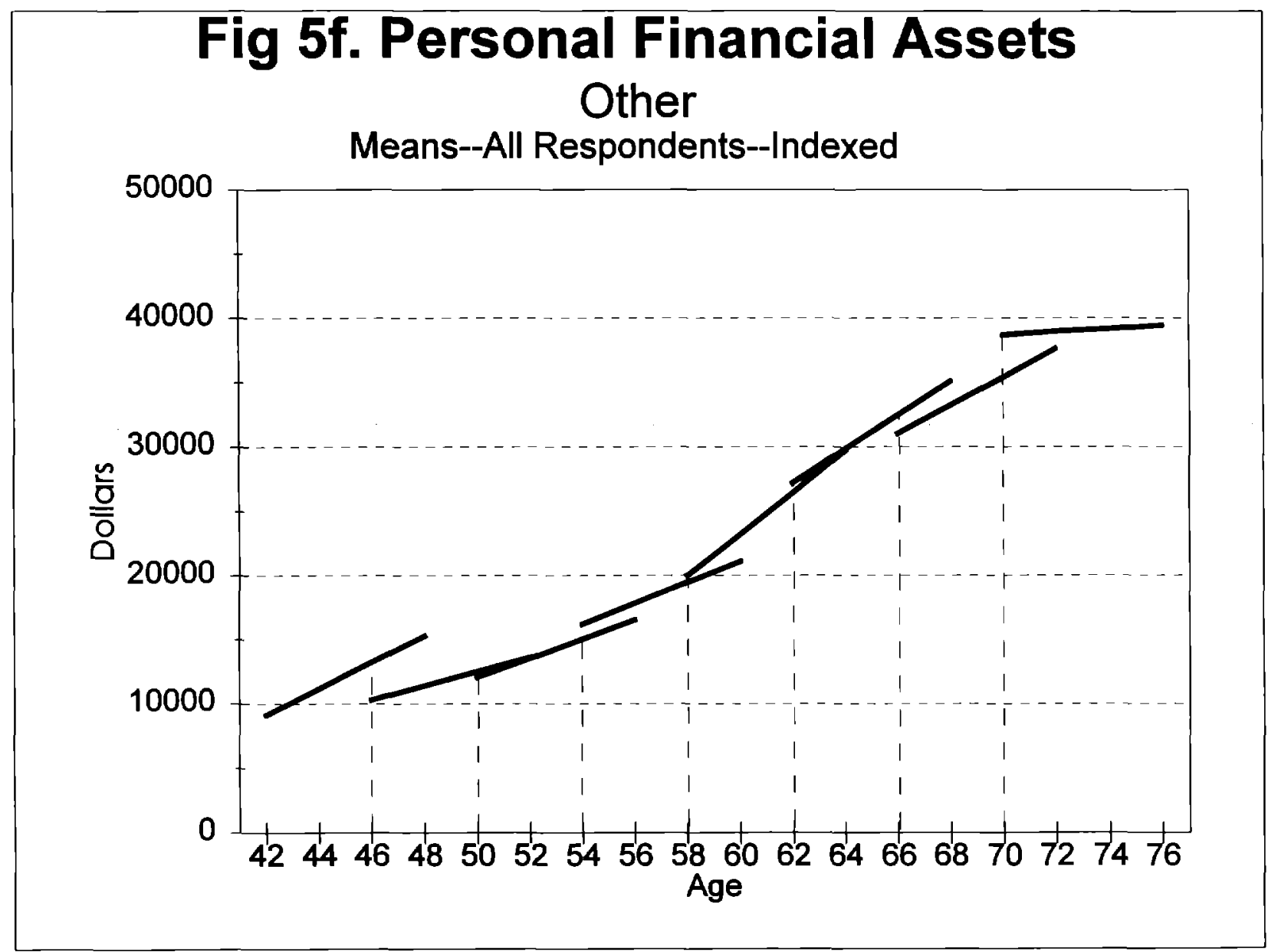




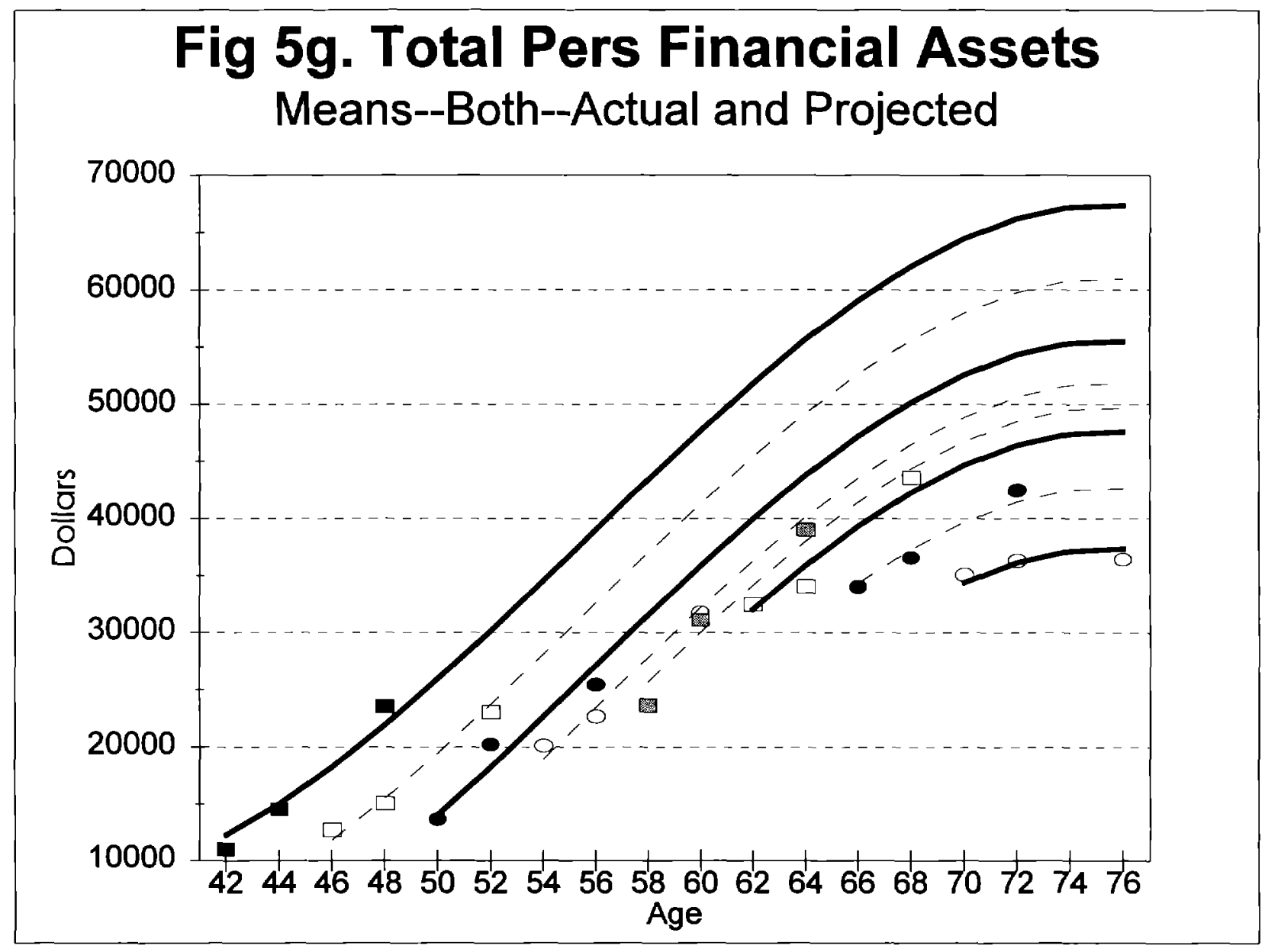




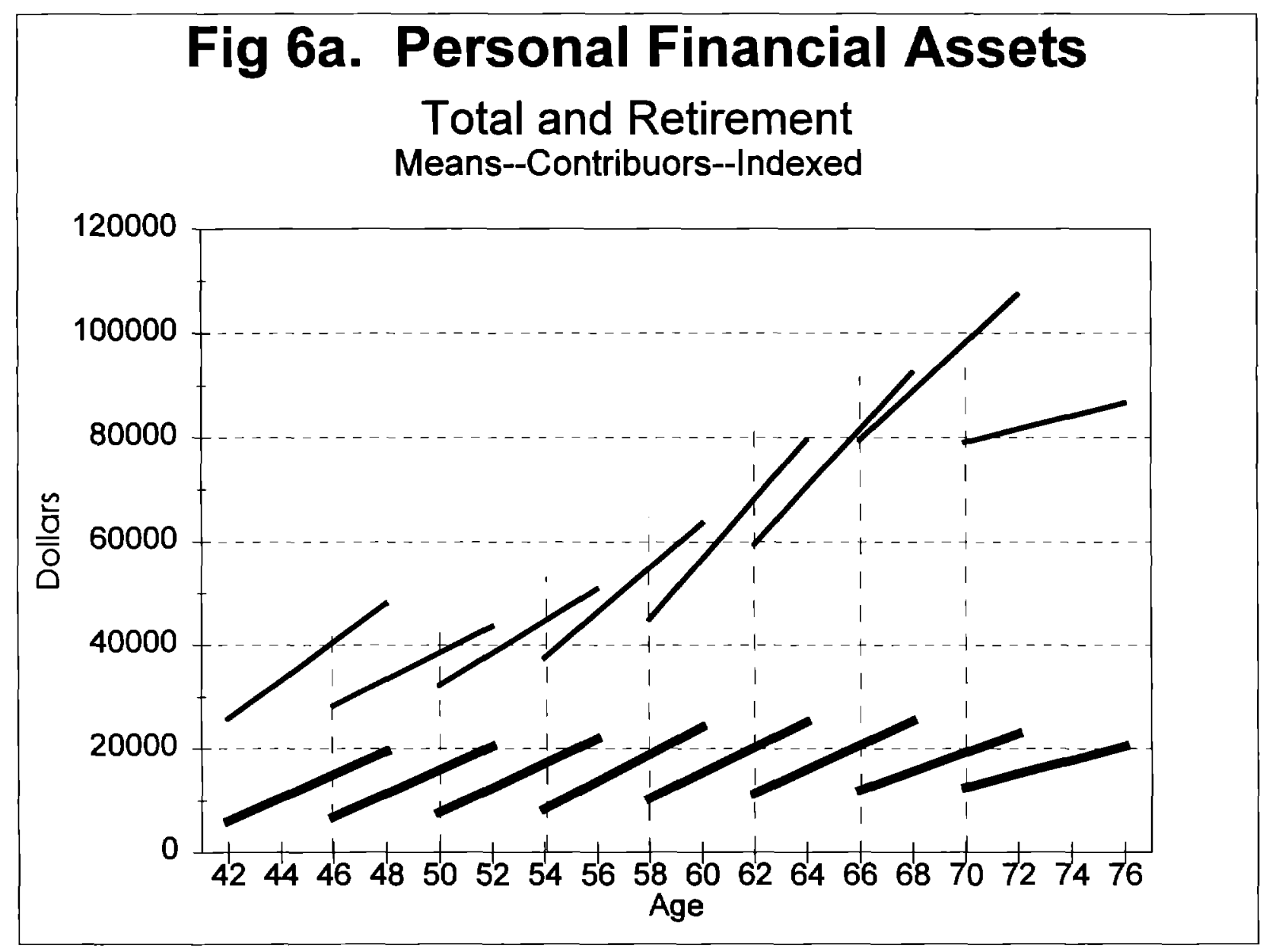




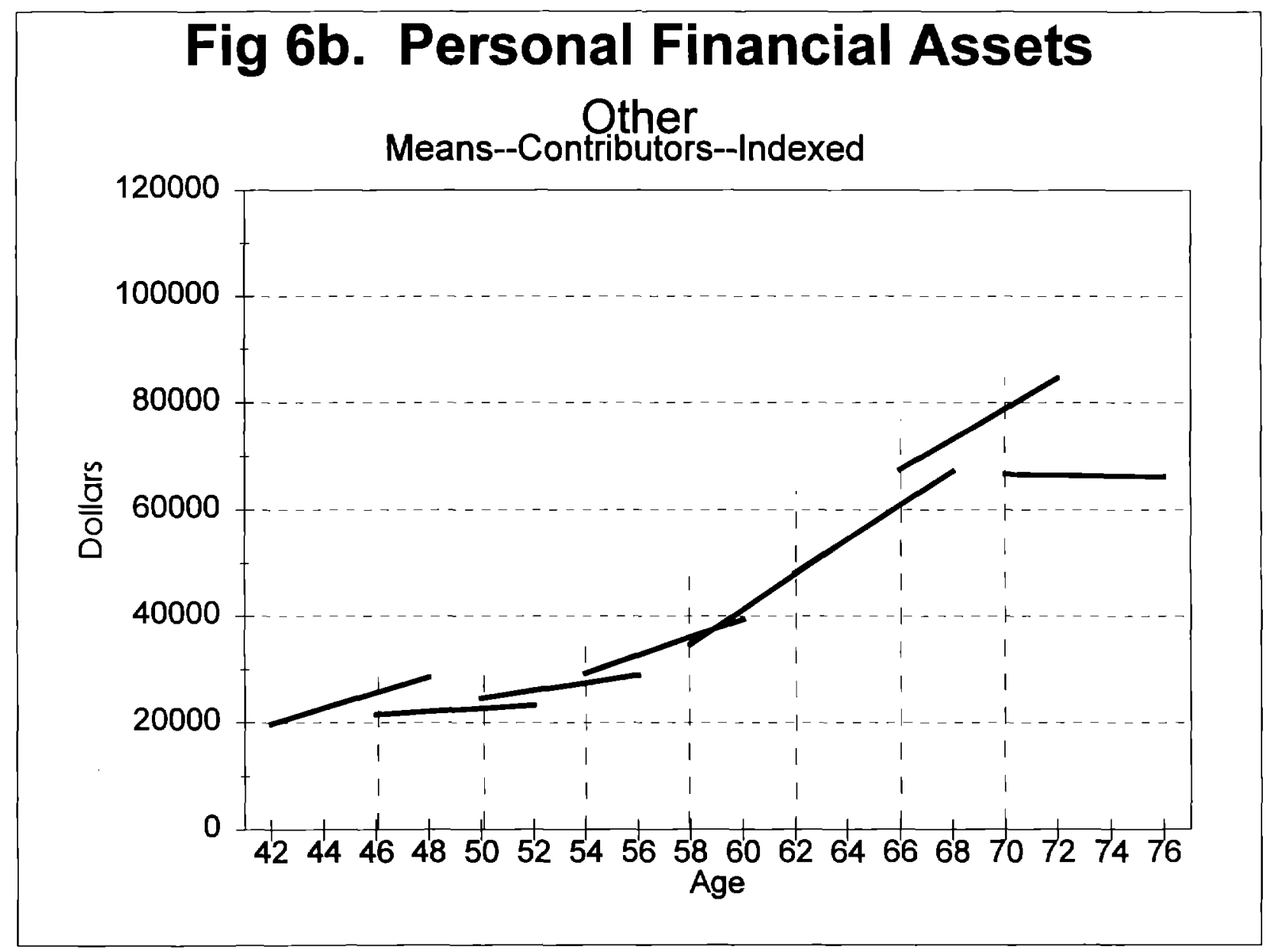




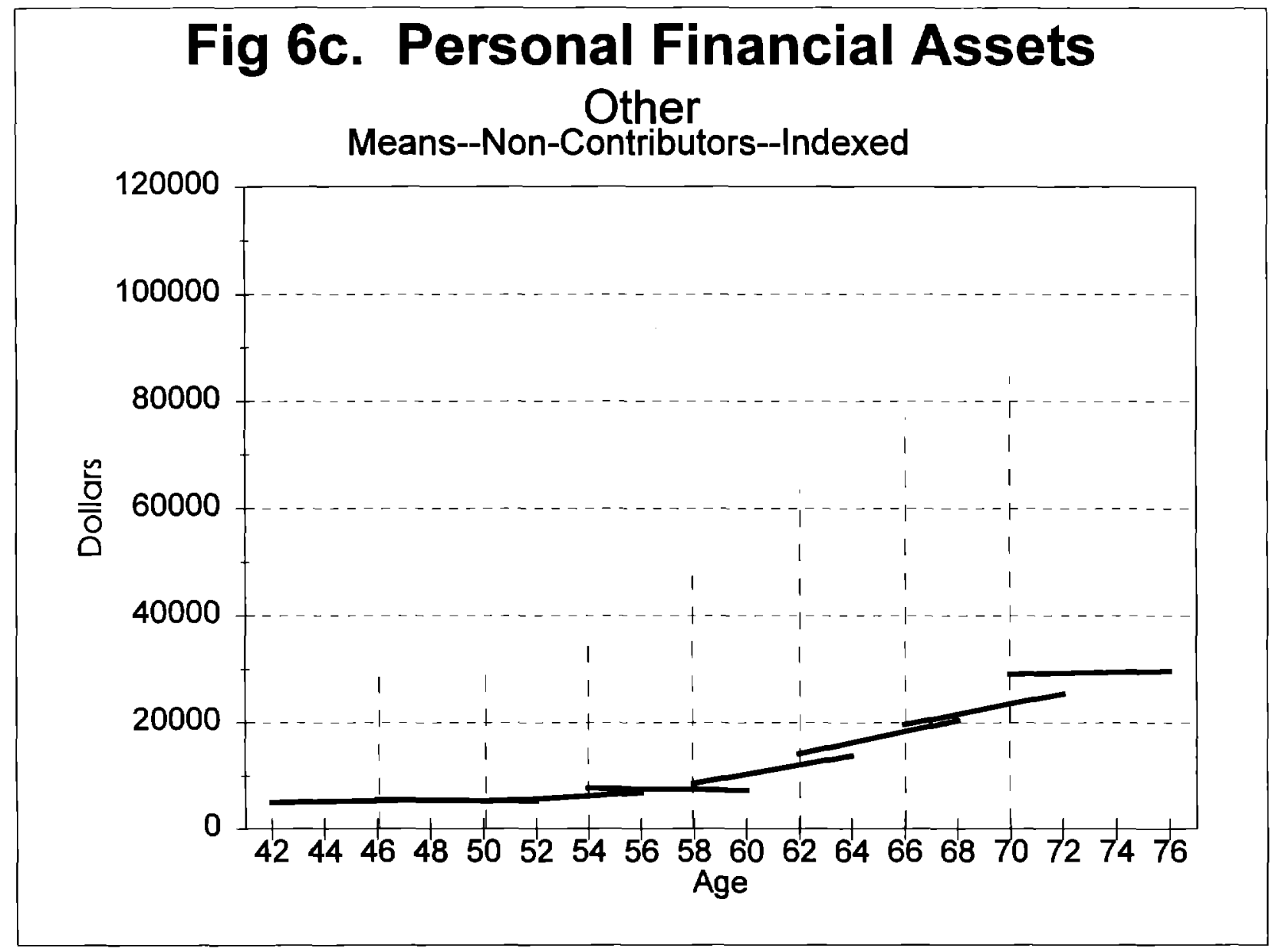




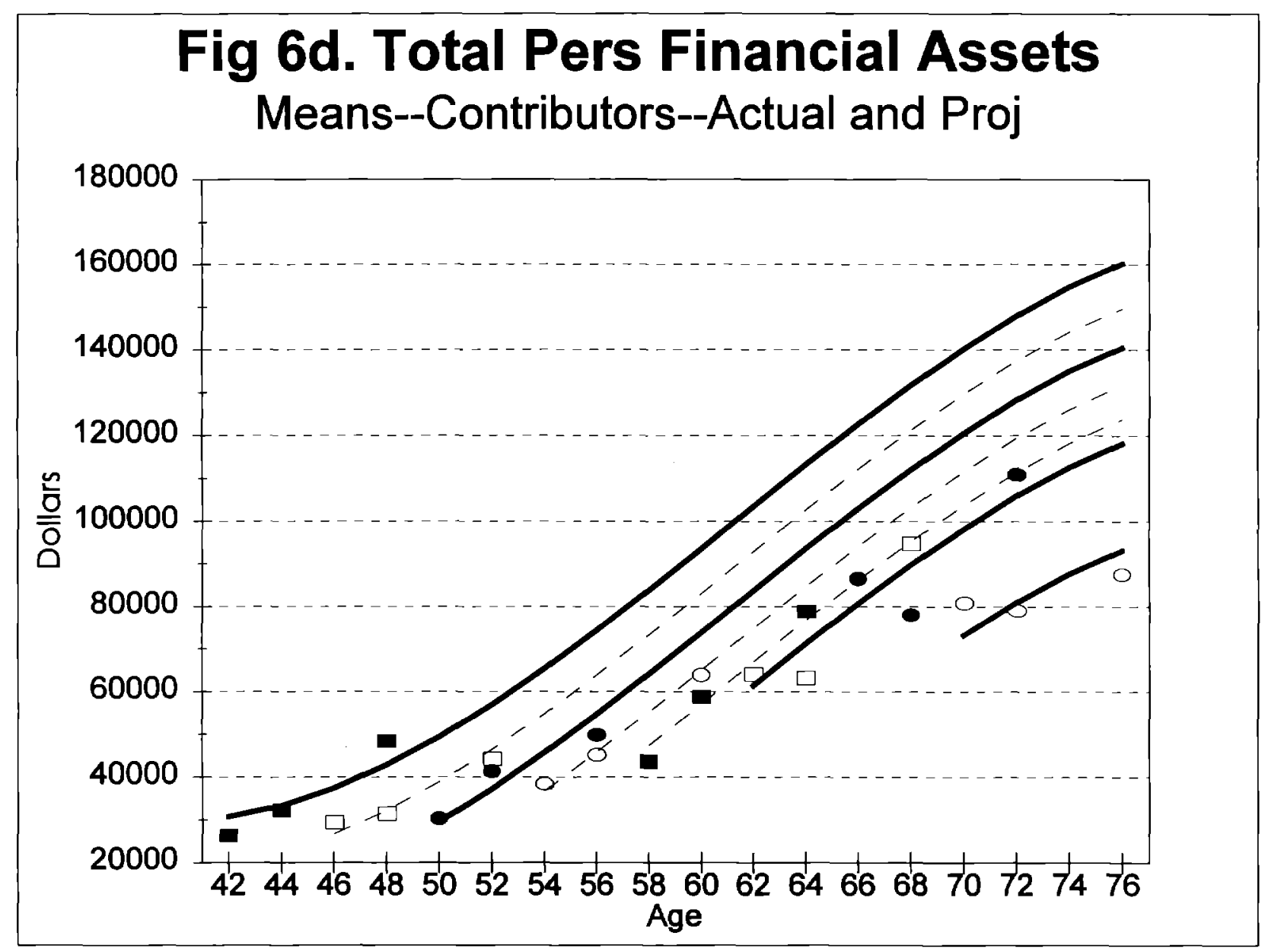




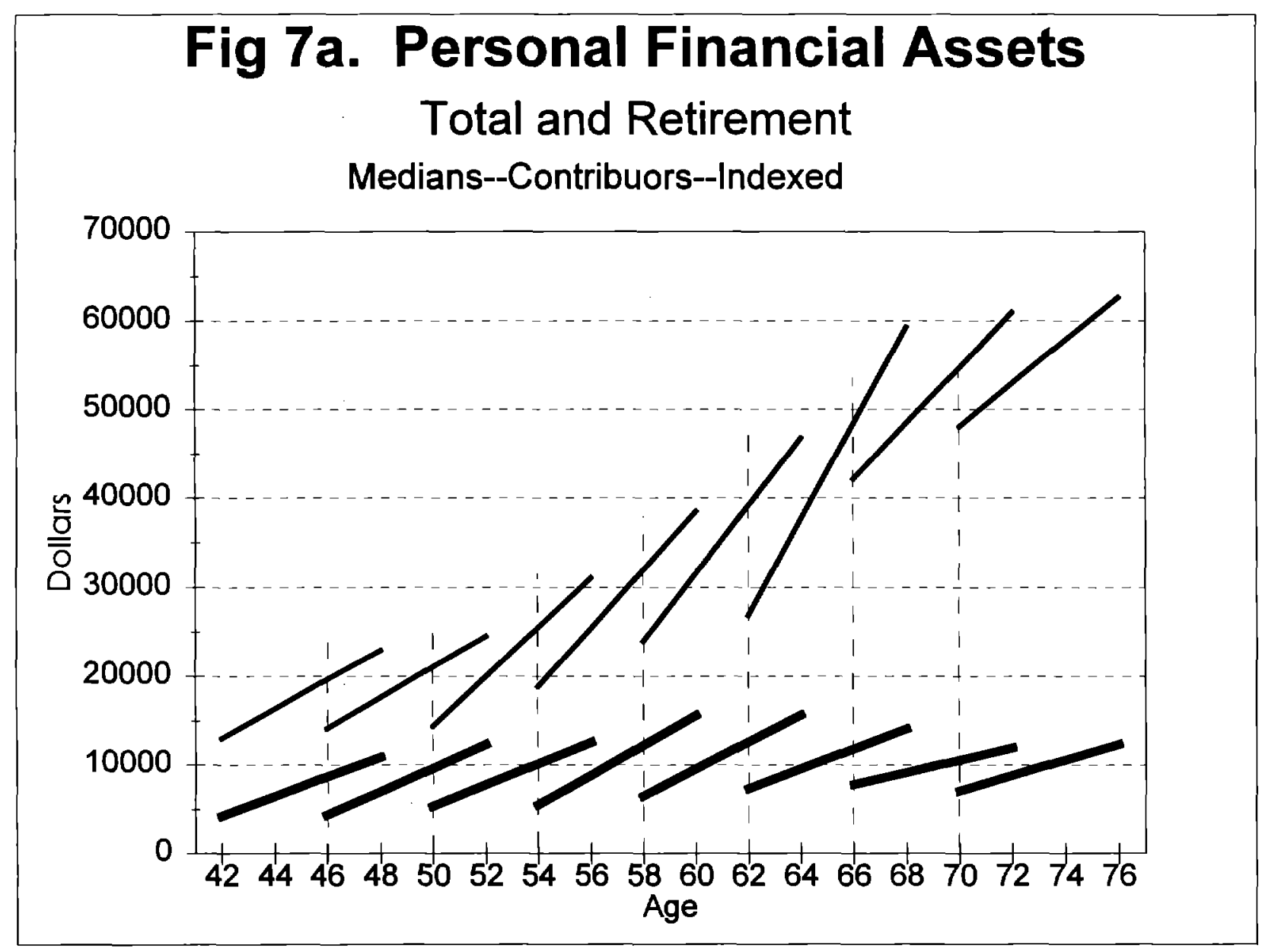




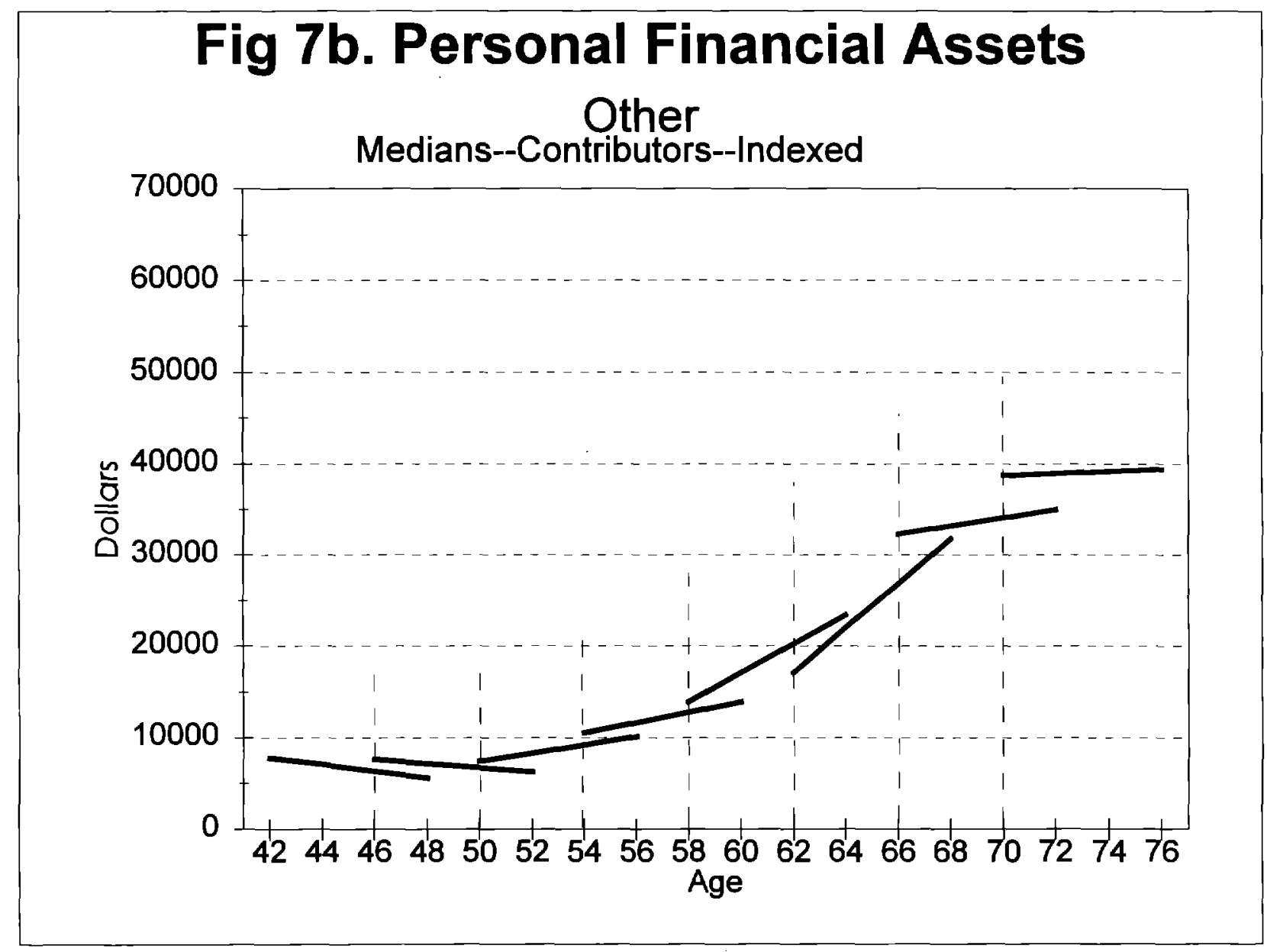




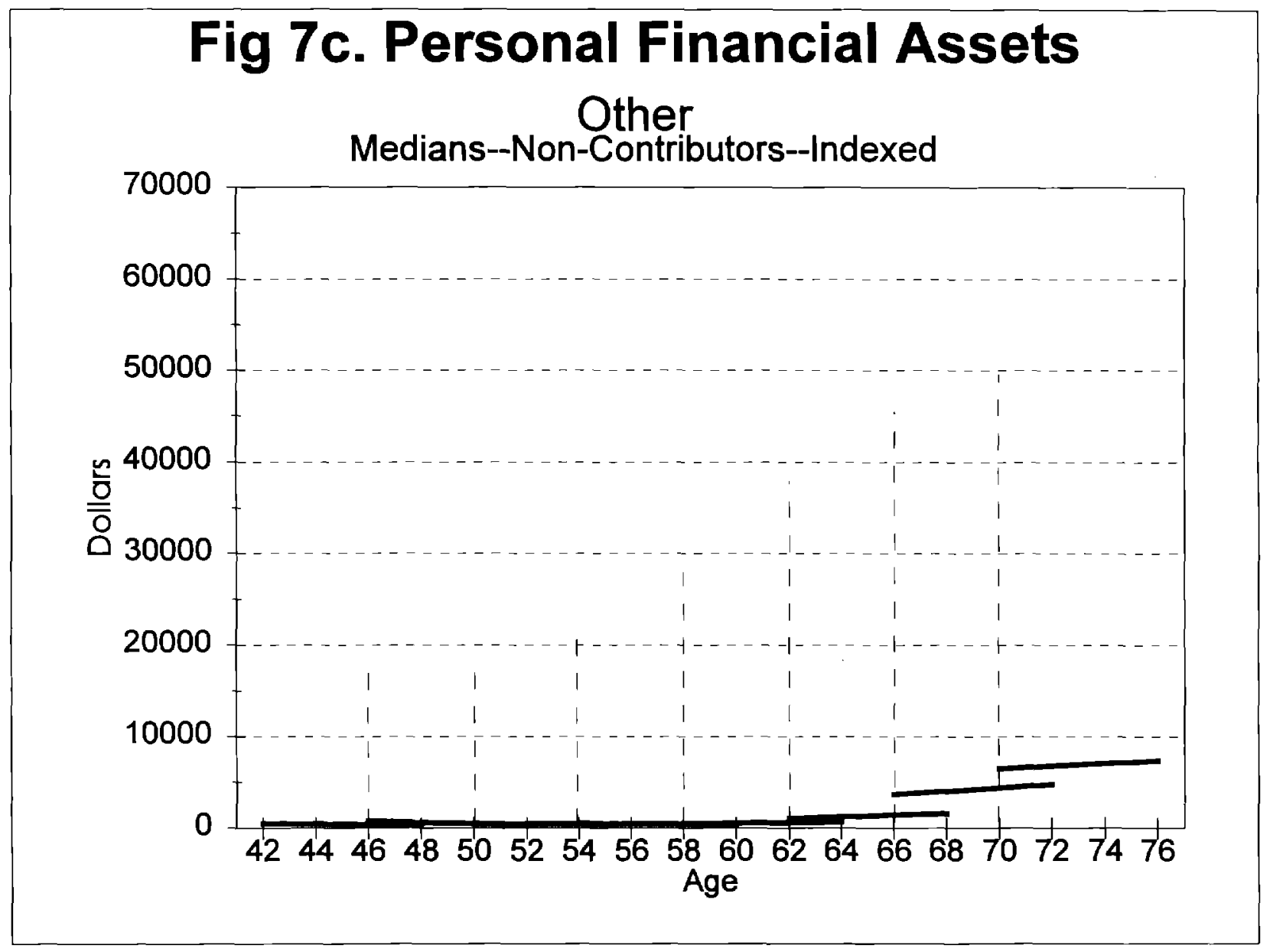




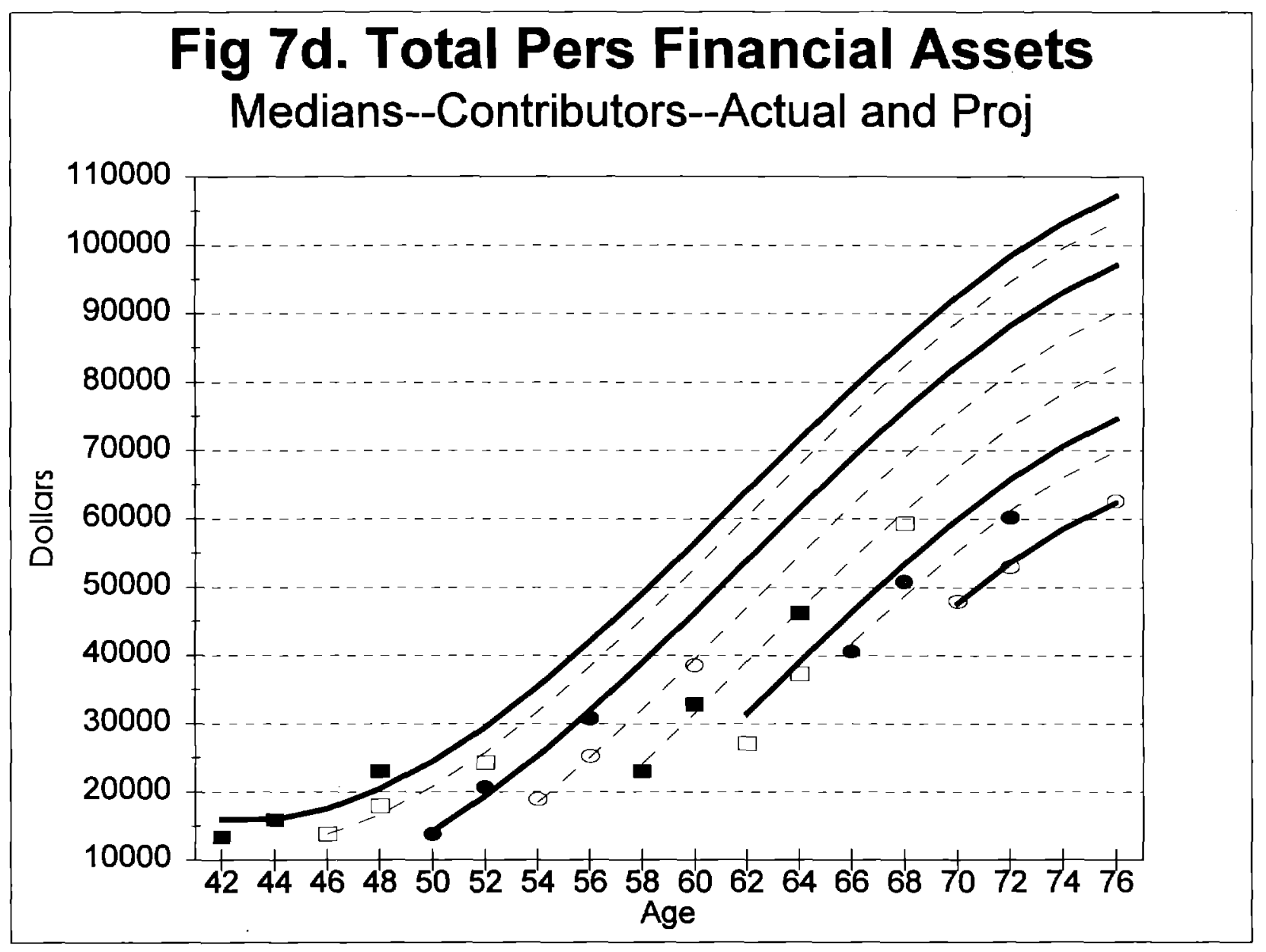




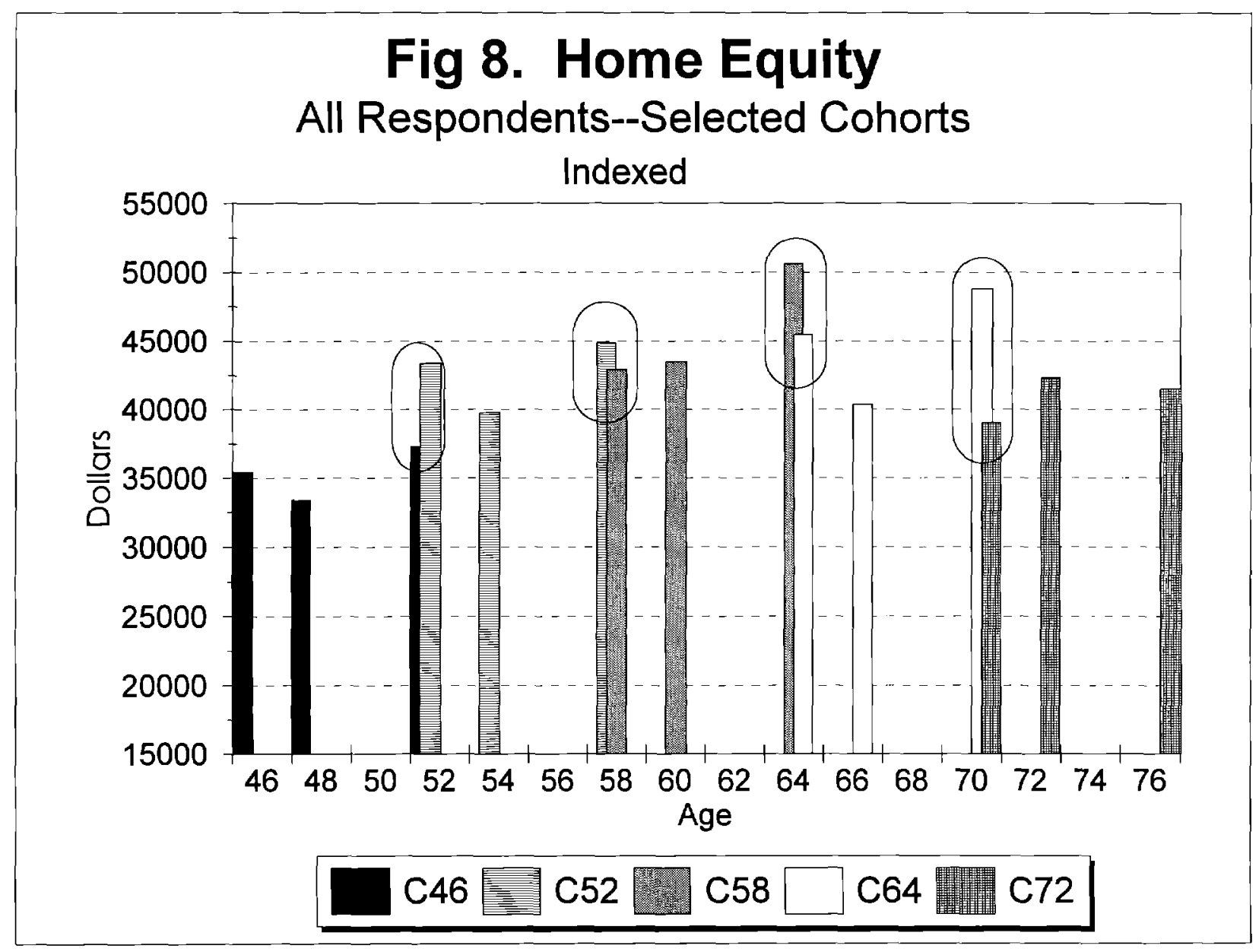

